\title{
Impact of Nickel Agglomeration on Solid Oxide Cell Operated in Fuel Cell and Electrolysis Modes
}

\author{
M. Hubert ${ }^{\mathrm{a}, \mathrm{b},{ }^{*}}$, J. Laurencin ${ }^{\mathrm{b}}$, P. Cloetens ${ }^{\mathrm{a}}$, B. Morel $^{\mathrm{b}}$, D. Montinaro ${ }^{\mathrm{c}}$, F. Lefebvre-Joud ${ }^{\mathrm{b}}$ \\ ${ }^{a}$ European Synchrotron Radiation Facility (ESRF), 71 avenue des Martyrs, 38000, Grenoble, France \\ ${ }^{\mathrm{b}}$ Univ. Grenoble Alpes - CEA/LITEN, 17 rue des Martyrs, 38054, Grenoble, France \\ c SOLIDpower S.p.A., 38017 Mezzolombardo, Italy
}

\begin{abstract}
Long-term experiments have been carried out to investigate the impact of Nickel (Ni) coarsening on the performance of Solid Oxide Cell. Durability tests have been performed with $\mathrm{H}_{2}$ electrode supported cells at $850^{\circ} \mathrm{C}$ and $750{ }^{\circ} \mathrm{C}$ in fuel cell and electrolysis modes. Microstructural changes in the composite electrode of Nickel and Yttria Stabilized Zirconia (YSZ) have been characterized by synchrotron X-ray nanotomography. Analysis of the reconstructions have revealed that $\mathrm{Ni}$ coarsening induces a significant decrease of both the density of Triple Phase Boundary lengths (TPBls) and the Ni/gas specific surface area. However, the contact surface between $\mathrm{Ni}$ and YSZ is not changed upon operation, meaning the Ni sintering is inhibited by the YSZ backbone. Moreover, the Ni coarsening rate is independent of the electrode polarization. The evolution of TPBls in operation has been fitted by a phenomenological law implemented in an electrochemical model. Simulations have shown that microstructural changes in the $\mathrm{H}_{2}$ electrode explain $\sim 30 \%$ of the total degradation in fuel cell mode and $\sim 25 \%$ in electrolysis mode at $850{ }^{\circ} \mathrm{C}$ after 1000-2000 h. Moreover, it has been highlighted that the temperature at which the degradation is estimated after the durability experiment plays a major role on the result.
\end{abstract}

Keywords: SOFC, SOEC, Ni coarsening, tomography, modelling.

*Corresponding author: Telephone: +33 (0)476882317, E-mail: maxime.hubert@esrf.fr 


\section{Introduction}

Solid Oxide Cells (SOCs), for either fuel cell (SOFC) or electrolysis (SOEC) operation, are being given a pronounced interest as they can offer high conversion efficiency due to their high operating temperature. Thanks to their reversibility, the same device can be alternatively used in fuel cell and steam electrolysis modes. Taking advantage of these characteristics, it has been proposed to couple the SOCs with intermittent renewable energy sources in order to match the fluctuations between the electricity demand and the production [1]. Besides, as part of the energy is supplied in the form of heat, the electrical demand required for the water splitting can be significantly reduced in SOEC mode [2].

The SOCs consist of two porous electrodes separated by a dense electrolyte. Typical materials for SOCs are Yttria-Stabilized Zirconia (YSZ) for the electrolyte, Ni-YSZ cermet for the $\mathrm{H}_{2}$ electrode and Lanthanum Strontium Cobalt Ferrite (LSCF) for the $\mathrm{O}_{2}$ electrode. In planar configuration, the cells are assembled with metallic interconnects to form a stack of high power density [3-5]. Nowadays, the SOCs durability is one of the main issues of the technology especially when operated in electrolysis mode. Indeed, the economic viability of the technology would be achieved for degradation limited to few tenth of percent $(<0.5 \% / \mathrm{kh})$. However, the degradation rates, which are in the range of $\approx 1 \% / \mathrm{kh}$ for stacks operated in fuel cell mode, can be increased to $\approx 2-3 \% / \mathrm{kh}$ for operation in electrolysis condition [6-9]. The loss in cell performances has been ascribed to various physical processes promoted by the high operating temperatures such as electrode poisoning, material instabilities, interdiffusion and reactivity [10-14]. Among all these phenomena, the microstructural evolution of the Ni-YSZ cermet is recognised to play a significant role in the global deterioration of SOCs performances [15-18].

The morphological change in the cermet microstructure is related to the Nickel phase coarsening that arises upon operation at high temperature [15]. The Ni particle growth results in the decrease of the density of Triple Phase Boundary lengths (TPBls) where the electronic, ionic and gas phase meet [17,19-22]. As TPBls are key parameters corresponding to the electro-active sites for the electrochemical reaction of charge transfer, it has been experimentally shown that the $\mathrm{Ni}$ agglomeration induces a substantial decrease of the electrode polarization resistance [16,23-26]. 
Therefore, many efforts have been paid to measure the growth of the Ni particle size as a function of the operating time on two-dimensional Scanning Electron Microscope (SEM) micrographs [15, 19, 25-27]. In order to quantify the loss in the density of TPBls, some authors have also reconstructed aged electrodes by X-ray tomography [17,21] or by using a Focused Ion Beam combined with a SEM (FIB-SEM) [16,22,28,29]. The introduction in electrochemical models of the microstructural properties estimated on the $2 \mathrm{D}$ cross sections or measured on the $3 \mathrm{D}$ reconstructed volumes has allowed the quantification of the effect of $\mathrm{Ni}$ coarsening on the electrode and cell response $[17,19,25]$.

The precise mechanisms responsible for the Ni microstructural change are not fully understood yet. Nevertheless, it is nowadays well established that two distinct underlying phenomena are involved in the Ni agglomeration:

- The first one is related to a kind of Ostwald ripening process based on the local sintering of two adjacent particles $[27,30]$. In this process, the main driving force would be the minimization of the $\mathrm{Ni}$ specific surface area with the growth of the biggest particles to the detriment of the smallest ones [31]. The mechanism, which involves a mass transfer at short-distance, could be controlled by (i) a solid-state diffusion of vacancies [30,31], (ii) a surface diffusion involving the transfer of $\mathrm{Ni}$ atoms or $\mathrm{Ni}_{2}-\mathrm{OH}$ species [30-35] or (iii) a transport in the gas phase by a local $\mathrm{Ni}$ vaporisation/condensation under $\mathrm{Ni}(\mathrm{OH})_{2}$ volatile molecules [36,37]. The validity of this mechanism in the cermet has been demonstrated thanks to microstructural observations after operation, which have highlighted the local Ni reorganisation with a shift of the Particle Size Distribution (PSD) toward bigger particles [15,17]. Besides, as expected for this process, it has been shown that the kinetic rate of the Ni particle growth decreases with increasing operating time $[19,25]$. Moreover, the YSZ backbone in contact with the Ni particle network is expected to interfere with the mechanism by lowering the sintering rates of the metallic phase $[33,34]$. However, this presumed inhibiting effect of the YSZ on the Ni agglomeration has not yet been experimentally proven.

- In parallel to the first process, observations of global compositional change within the electrode have been attributed to a mechanism based on a mass transfer at long-distance. In this case, after vaporisation into $\mathrm{Ni}(\mathrm{OH})_{2}$ volatile molecules, Nickel could be transported into the gas phase either by diffusion in the cermet porosity or even by convection in the channel of gas distribution 
$[17,27,33,36]$. In contrast to the first mechanism, the kinetic rate of the Ni evaporation/deposition process should not slow down over time, and hence, could be predominant only for very long operating times [27]. Besides, it has been observed that the process tends to deplete the electrode/electrolyte interface with a displacement of $\mathrm{Ni}$ in the bulk part of the cermet [38-40]. It has been proposed by Mogensen et al. [38] that the mechanism could be promoted at high electrode polarisation. However, the real extent of this mass transfer is still unclear. For example, Hagen et al. [39] and Mogensen et al. [38] have reported a massive Ni depletion whereas Rinaldi et al. [40] have only observed a very slight relocation of Ni even after an operation of $10700 \mathrm{~h}$. This apparent discrepancy points out that the Ni coarsening mechanisms must be strongly dependent on both the operating conditions and the cermet microstructure. Indeed, in contrast to Rinaldi et al. [40], the cells tested in Mogensen et al. [38] present a functionalisation of the electrode with a fine microstructure at the interface with the electrolyte (i.e. a functional layer designed for the electrochemistry).

The operating temperature has been found to have a major role on the Ni agglomeration. Indeed, the Ni particle coarsening is based on a sintering process which is thermally activated $[41,42]$. Therefore, it has been shown that the $\mathrm{Ni}$ agglomeration is favoured when the temperature is increased [29,39]. However, this observation is apparently inconsistent with the measured electrochemical degradation rates that are found to decrease with increasing the temperature [39]. It has also been observed that the steam content in the gas stream accelerates the Ni agglomeration $[27,29,33]$. Indeed, the presence of water in the gas phase is liable to affect both mechanisms, by promoting the vaporisation of the $\mathrm{Ni}(\mathrm{OH})_{2}$ gaseous molecules and the surface diffusion of the $\mathrm{Ni}$ hydroxide complex [27,33]. Finally, it is worth noting that most of the studies have been performed in fuel cell mode whereas very few have been dedicated to the electrolysis conditions [17,38]. No specific studies have been conducted to compare the effect of polarisation in SOFC and SOEC modes on the Ni coarsening.

In this work, it is proposed to investigate the impact of the temperature and the SOFC/SOEC polarization on the Ni coarsening. For this purpose, a set of long term tests has been carried out in the two modes at different temperatures. 3D reconstructions of the cermet electrodes have been acquired by X-ray nanotomography in the bulk and at the electrode/electrolyte interface. After 
verification that, in our conditions, the $\mathrm{Ni}$ depletion at the electrolyte interface is limited and the change in Ni volume fraction in the bulk is negligible, the evolution of the cermet microstructural properties has been analyzed to study the mechanism of Ni particles growth based on a local sintering process. After identifying the parameters for a relevant law, the impact of $\mathrm{Ni}$ agglomeration on the cell response has also been modelled and discussed.

\section{Experimental details}

\subsection{Materials and cell description}

Typical $\mathrm{H}_{2}$ electrode supported cells representative of the SOC technology have been used in this work. They have been provided by SOLIDPower ${ }^{\circledR}$ company. The cells exhibit a circular shape with an active area of $9 \mathrm{~cm}^{2}$. The electrolyte made of $8 \% \mathrm{~mol}$ Yttria Stabilized Zirconia (YSZ) is a dense and thin film of $5 \mu \mathrm{m}$. It is coated onto a $260 \mu \mathrm{m}$ thick porous $\mathrm{H}_{2}$ electrode substrate composed of Nickel and YSZ (Ni-YSZ) cermet. The $\mathrm{O}_{2}$ electrode presents a multilayer structure which is deposited onto the electrolyte. The active part of the $\mathrm{O}_{2}$ electrode is a porous bilayer constituted of a composite made of $\mathrm{La}_{0.6} \mathrm{Sr}_{0.4} \mathrm{Co}_{0.2} \mathrm{Fe}_{0.8} \mathrm{O}_{3-\delta}$ (LSCF) and $10 \% \mathrm{~mol}$ Ceria doped Gadolinium Oxide (LSCF- CGO) (ca. $15 \mu \mathrm{m}$ thick) associated to a pure LSCF layer (ca. $18 \mu \mathrm{m}$

thick). In order to limit the chemical reactivity between LSCF and YSZ, a thin barrier layer of CGO (ca. 2-3 $\mu \mathrm{m}$ thick) is added between the electrolyte and the $\mathrm{O}_{2}$ electrode. Finally, a $20 \mu \mathrm{m}$ thick $\mathrm{La}_{0.5} \mathrm{Sr}_{0.5} \mathrm{CoO}_{3}$ (LSC) layer is coated on the top of the oxygen electrode to improve the current collection. The $\mathrm{H}_{2}$ electrode and the electrolyte were manufactured by water based tape casting and co-sintered. Then, the barrier layer and the $\mathrm{O}_{2}$ electrode were applied on the electrolyte by screen printing.

\subsection{Electrochemical set-up and test conditions}

Long-term durability tests have been performed with an in-house set-up already detailed in [43]. The anodic and cathodic gases are introduced at the cell center according to a radial co-flow configuration. The gas tightness of the $\mathrm{H}_{2}$ compartment is ensured by a glass seal deposited at the cell periphery. The electrical current is collected by a Gold and a Nickel grid of $100 \mathrm{mesh} . \mathrm{cm}^{-2}$ at 
the $\mathrm{O}_{2}$ and $\mathrm{H}_{2}$ sides, respectively. To enhance the electrical contact, a mechanical load of 400 g. $\mathrm{cm}^{-2}$ is applied on the set-up. The temperature is controlled by a thermocouple positioned in the gas stream at the cell outlet. A bubbler is used to humidify the hydrogen before the cell entrance. A buffer was connected to the bubbler outlet to absorb the pressure variation in order to limit the steam flow oscillation and reduce the noise on the cell voltage.

The same protocol has been used to start all the experiments before the durability tests and is detailed hereafter. The cell is heated up to $900{ }^{\circ} \mathrm{C}$ at a rate of $1{ }^{\circ} \mathrm{C} \cdot \mathrm{min}^{-1}$ by sweeping the $\mathrm{O}_{2}$ and $\mathrm{H}_{2}$ compartments under air and nitrogen, respectively. After $30 \mathrm{~min}$, the temperature is decreased to $860^{\circ} \mathrm{C}$ for a step of $90 \mathrm{~min}$ in order to complete the formation of the glass seal. Once the gas tightness of the $\mathrm{H}_{2}$ compartment is achieved, the cermet reduction is conducted at $800{ }^{\circ} \mathrm{C}$. For this purpose, the hydrogen content in the gas flow is gradually increased up to reach a pure hydrogen atmosphere. This condition is maintained for 2 hours with a $\mathrm{H}_{2}$ flow rate of $5.8 \mathrm{NmL} \cdot \mathrm{min}^{-1} \cdot \mathrm{cm}^{-2}$, whereas the $\mathrm{O}_{2}$ electrode is fed with air at a flow rate of $41.5 \mathrm{NmL} \cdot \mathrm{min}^{-1} \cdot \mathrm{cm}^{-2}$. After the cermet reduction treatment, a polarization curve is recorded under the same experimental conditions to control the initial cell performances as well as the gas tightness of the $\mathrm{H}_{2}$ compartment. After the durability tests, the cell is cooled at room temperature with the $\mathrm{H}_{2}$ electrode fed with a mixture of nitrogen and hydrogen to keep the cermet in its reduced state.

The experimental conditions of the long-term tests are summarized in Table I. They were performed in galvanostatic mode at current densities varying between -0.75 and $-0.5 \mathrm{~A} . \mathrm{cm}^{-2}$ in electrolysis mode and $+0.5 \mathrm{~A} . \mathrm{cm}^{-2}$ in fuel cell mode. In order to accelerate the material ageing upon operation, a temperature of $850^{\circ} \mathrm{C}$ was taken for all experiments except for the Cell $n^{0} 5$. In this case, the long test was conducted at lower temperature $\left(750^{\circ} \mathrm{C}\right)$ to investigate the role of this operating parameter on the degradation. The Steam Conversion (SC) rate or Fuel Utilization (FU) have been kept at a constant value. At the $\mathrm{O}_{2}$ electrode side, a rather low conversion rate of $20 \%$ was taken to limit the oxygen partial pressure gradient along the cell length. It should be noticed that the experiments from Cell $\mathrm{n}^{0} 1$ to Cell $\mathrm{n}^{\circ} 4$ were carried out with a $\mathrm{H}_{2} / \mathrm{H}_{2} \mathrm{O}$ ratio of $50 / 50$ (2.54 g.h h $^{-1}$ of $\mathrm{H}_{2} \mathrm{O}$ added to gas stream of Cell $\mathrm{n}^{0} 1,2$ and $4 ; 3.81 \mathrm{~g}^{-h^{-1}}$ for Cell $\mathrm{n}^{\circ} 3$ ). This composition was chosen to keep the same Open Circuit Voltage (OCV) whatever the operating condition in fuel cell or electrolysis mode. This choice allows a direct comparison of the 
degradation rates recorded in SOFC (Cell $n^{\circ} 1$ and $\left.n^{\circ} 2\right)$ or SOEC (Cell $\left.n^{\circ} 4\right)$ mode assuming that the other operating conditions are the same.

Table I - Operating conditions for the galvanostatic long-term tests.

\begin{tabular}{ccccccc}
\hline Cell & Mode & $\mathrm{T}\left({ }^{\circ} \mathrm{C}\right)$ & $\mathrm{O}_{2} / \mathrm{N}_{2}$ & $\mathrm{H}_{2} / \mathrm{H}_{2} \mathrm{O}$ & $\mathrm{i}\left(\mathrm{A} . \mathrm{cm}^{-2}\right)$ & $\mathrm{SC} / \mathrm{FU}(\%)$ \\
\hline $\mathbf{1}$ & SOEC & 850 & $21 / 79$ & $50 / 50$ & -0.5 & 60 \\
\hline $\mathbf{2}$ & SOEC & 850 & $21 / 79$ & $50 / 50$ & -0.5 & 60 \\
\hline $\mathbf{3}$ & SOEC & 850 & $21 / 79$ & $50 / 50$ & -0.75 & 60 \\
\hline $\mathbf{4}$ & SOFC & 850 & $21 / 79$ & $50 / 50$ & +0.5 & 60 \\
\hline $\mathbf{5}$ & SOFC & 750 & $21 / 79$ & $100 / 0$ & +0.5 & 60 \\
\hline
\end{tabular}

2.3 X-ray nanotomography characterization and electrode properties quantification

Synchrotron X-ray holographic nanotomography experiments have been performed on the NanoImaging ID16A beamline at the European Synchrotron Radiation Facility (ESRF, Grenoble, France). This beamline has been designed with the objective to combine a high spatial resolution and a large field of view for the 3D reconstructed images. To achieve this goal, the $\mathrm{X}$-ray beam is nano-focused by Kirkpatrick-Baez mirrors specifically manufactured for the two energies available on the beamline of $17 \mathrm{keV}$ and $33.6 \mathrm{keV}$ [44]. These two energies are especially well adapted to penetrate without too much attenuation the SOC electrodes made of strongly X-ray absorbing ceramics. In practice, magnified projections of the sample are recorded at four different positions between the focal plane and sample and at a large number of angular positions over half a turn [45]. Furthermore, to remove inhomogeneities coming from the incident beam, the original procedure has been adapted by Hubert et al. [46]. It basically consists in adding random motions of the sample between each position of the rotation process. After the data acquisition on the beamline, a holographic scheme is used to retrieve the phase information by using dedicated programs implemented on GNU Octave software. The tomographic reconstruction is performed with the so-called filtered back projection algorithm to obtain the final 3D reconstruction [47]. The overall method and procedures have been specifically adapted for the SOC electrodes $[46,48,49]$. In this case, the tomography samples are micro-pillars of 50-100 $\mu \mathrm{m}$ in diameter which are directly extracted from the cell by using a Plasma Focused Ion Beam (P-FIB Vion, FEI ${ }^{\circledR}$, Hillsboro, OR, USA) working with Xenon [49]. After reconstruction, the 3D volumes present a large field of view $(50 \mu \mathrm{m})$, a small voxel size $(25 \mathrm{~nm})$ and a high spatial resolution as small as 50 
$\mathrm{nm}$ [49]. The 3D image in grey levels is filtered and segmented with the procedures already presented in previous works [48]. The electrode microstructural properties are then computed on the segmented volumes with an in-house numerical software thoroughly detailed in other articles [50-52].

For the present study, tomography experiments have been performed on samples taken from the Ni-YSZ electrode of the pristine cell and after the durability experiments. The raw data have been acquired in the bulk of the cermet at a distance of few tens of micrometers from the electrode/electrolyte interface in order to avoid the zone affected by the Ni depletion. To check the real extent of this zone, 3D volumes have been also reconstructed at the electrode/electrolyte interface. Besides, the micro-pillars for the tomography experiments have been taken at the cell inlet for the tests $n^{\circ} 1,2,3$ and 4 where the water content in operation was the same (i.e. $\% \mathrm{H}_{2} \mathrm{O}=50 \%$ : cf. Table I). For the test $\mathrm{n}^{\circ} 5$ performed in SOFC mode under dry $\mathrm{H}_{2}$, the reconstruction has been carried out with a specimen taken at the cell outlet so that the steam condition can be roughly considered identical with the other samples. These localizations for the $3 \mathrm{D}$ reconstructions allow putting aside the effect of steam partial pressure in such a way that only the impact of temperature and polarization on Ni coarsening has been investigated in the present study.

For all the reconstructions, the microstructural properties have been measured on the percolated phases. In particular, the phase volume fraction, the mean phase diameters, the tortuosity factors, the specific surface areas as well as the density of TPBls have been quantified on the 3D reconstructions.

\subsection{SEM characterizations}

Complementary to the tomography reconstructions, the Ni-YSZ cermets of the pristine and the tested cells have also been observed with a Field Emission Gun Scanning Electron Microscope (FEG-SEM Zeiss Merlin, Oberkochen, Germany). To prepare the polished cross sections, the cells were cut with a wire saw. The pieces were then embedded under pressure with a polymer resin (Epofix ${ }^{\circledR}$, Denmark) so that the open porosity was filled by the resin. Finally, the samples were 
gradually polished using a diamond spray of $1 / 4 \mu \mathrm{m}$ for the final stage. The conditions for the SEM observations have been optimized to enhance the contrast between YSZ, Ni and the pores. To this objective, the observations were realized in Secondary Electrons (SE) mode at a low acceleration voltage $(0.5 \mathrm{kV})$ while the working distance between the sample and the SE detector was lowered to $2-3 \mathrm{~mm}$.

\section{Results}

\subsection{Initial cell performances and durability tests}

Initial cell performances acquired before the long-term tests are plotted on Fig. 1. Polarization curves have been measured at $850^{\circ} \mathrm{C}$ for both fuel cell and electrolysis modes. Additionally, polarization curves under dry hydrogen in SOFC mode were also recorded at $800{ }^{\circ} \mathrm{C}$. The main features of the $\mathrm{i}-\mathrm{V}$ curves are consistent with the characteristics already reported for the same kind of cells $[53,54]$. This observation validates the start-up protocol as well as the experimental setup. Moreover, rather good performances have been achieved whatever the operating conditions meaning that the studied cell is well representative of the standard SOFC/SOEC technology.

Typical durability curves recorded in galvanostatic mode at $+/-0.5 \mathrm{~A} . \mathrm{cm}^{-2}$ (i.e. for fuel cell and electrolysis currents) are illustrated on Fig. 2. After a short transient period of around 100-200 h, the curves show a linear evolution of the cell voltage as a function of time. The degradation rates reported in Table II have been determined on the steady-state regime of the durability curve. It can be noticed that two distinct values are given for Cell $\mathrm{n}^{0} 5$ which has been tested over more than one year. Indeed, in this particular case, apart from the short initial transition of 100-200 h, two other

periods have been detected on the curve. The first one lasted over the first $2000 \mathrm{~h}$ of the test while the second period went to the end of the experiment with a slightly lower degradation rate. As a general comment for all the tests, it is worth noting that rather slow evolutions of cell voltage upon operation have been recorded with degradation rates from $3.5 \pm 1$ to $15.8 \pm 3 \mathrm{mV} \mathrm{kh}^{-1}$ that range in the state-of-the-art of the typical values already reported in literature $[7,9,55]$. 
The effect of operating conditions on the durability behavior can be discussed from the degradation rates provided in Table II. As expected, the degradation rates between Cell $\mathrm{n}^{\circ} 1$ and Cell $\mathrm{n}^{\circ} 2$ are found to be equivalent since the operating conditions are similar. This observation validates the test repeatability and reliability together with the setup used for long-term durability experiments. As Cells $\mathrm{n}^{\circ} 1,2$ and 4 have been tested in the same conditions of temperature, gas feeding and current density at $+/-0.5 \mathrm{~A} . \mathrm{cm}^{-2}$, their durability behavior for an operation either in SOFC or SOEC modes can be directly compared and analyzed. It is found that the degradation rate in electrolysis mode is about three times higher than in fuel cell mode (cf. Table II). In other words, the loss of cell performances is found to be significantly higher under electrolysis current. This result points out that the higher cell polarization in electrolysis mode would accelerate the material ageing. The potential impact of electrode polarization on the Ni coarsening will be discussed in section 3.2. Besides, when comparing the degradation rate of Cell $\mathrm{n}^{\circ} 3$ tested at $-0.75{\mathrm{~A} . \mathrm{cm}^{-2}}^{-}$with Cell $\mathrm{n}^{\circ} 2$ operated at $-0.5 \mathrm{~A} . \mathrm{cm}^{-2}$, it appears that a higher current density results in an increase of the degradation rate. Nevertheless, when the voltage loss is evaluated on the polarization curve at the same current density after the durability experiment (i.e. at -0.5 A.cm ${ }^{-2}$ for Cell $\mathrm{n}^{0} 3$ ), it has been found that the degradations of Cell $n^{\circ} 3$ and Cell $n^{\circ} 2$ are almost identical. As a consequence, it seems that, in our conditions of test duration, the intrinsic degradation of SOC materials would be similar whatever the operating current density between -0.5 and $-0.75 \mathrm{~A} . \mathrm{cm}^{-2}$. Finally, it has been found that the degradation rate in fuel cell mode is substantiality more pronounced with Cell $\mathrm{n}^{0} 5$ operated at $750{ }^{\circ} \mathrm{C}$ than Cell $n^{\circ} 4$ aged in similar conditions at $850{ }^{\circ} \mathrm{C}$. This unexpected result, which has been already observed by other authors [39,56-58] will be discussed in the next section.

Table II - Degradation rates for the galvanostatic long-term tests.

\begin{tabular}{ccccc}
\hline Cell & Mode & $\mathrm{T}\left({ }^{\circ} \mathrm{C}\right)$ & Ageing time $(\mathrm{h})$ & Degradation rate $\left(\mathrm{mV} \cdot \mathrm{kh}^{-1}\right)$ \\
\hline $\mathbf{1}$ & SOEC & 850 & 1500 & $9.7 \pm 2.0$ \\
\hline $\mathbf{2}$ & SOEC & 850 & 2000 & $8.8 \pm 1.0$ \\
\hline $\mathbf{3}$ & SOEC & 850 & 2400 & $15.8 \pm 3.0$ \\
\hline $\mathbf{4}$ & SOFC & 850 & 1000 & $3.5 \pm 1.0$ \\
\hline $\mathbf{5}$ & SOFC & 750 & 9000 & $\left.\begin{array}{c}(1) \\
(2)\end{array}\right) .13 \pm 0.5(\mathrm{t}<2000 \mathrm{~h})$ \\
\hline
\end{tabular}




\subsection{Ni-YSZ microstructure evolution under operation}

SEM electrode observations - The SEM micrographs are illustrated in Fig. 3 for the fresh electrode and for Cell $\mathrm{n}^{\circ} 4$ and 5 after long-term operation in fuel cell mode (cf. Table II). It can be noticed that $\mathrm{Ni}$ particles seem to be well distributed on the whole electrode thickness without any clear $\mathrm{Ni}$ depletion detected at the interface between the $\mathrm{H}_{2}$ electrode and the electrolyte. The SEM observations for the other tested cells have led to the same conclusion whatever the polarization in fuel cell or electrolysis mode. Therefore, it can be inferred from this preliminary post-test characterization that, in our experimental conditions, the Ni volatilization at long-distance would be a minor process regarding the Nickel coarsening. As a consequence, the agglomeration should be rather controlled by mass transfer at short distance related to a local sintering process.

While no Ni depletion or change in the Ni distribution was detected, the visual comparison of the micrographs between the pristine and the operated cells clearly reveals a significant $\mathrm{Ni}$ coarsening (Fig. 3a compared to Fig. 3b and Fig 3c). Nevertheless, the quantification of the microstructural properties on the $2 \mathrm{D}$ image is not straightforward and requires assumptions on the topology of the electrode microstructure. To overcome this issue, 3D cermet reconstructions have been acquired by the X-ray nanotomography.

Ni coarsening in the $3 D$ electrode reconstructions - In agreement with the SEM characterizations, the inspection of the 3D volumes reconstructed at the interface with the electrolyte has not revealed any obvious Ni depletion after operation even in the vicinity of the electrode/electrolyte interface. Complementary with the characterizations at the interface, microstructural quantifications have been performed on the 3D volumes taken in the bulk of the electrode for all the tested cells. The measurements have shown that the cermet does not present any evolution of the phase volume fractions for $\mathrm{Ni}$, YSZ and porosity. These analyses indicate that the Ni redistribution at long distance within the cermet upon operation is not detectable in our case, and thus, confirm the conclusion inferred from SEM observations. They reinforce the statement that the $\mathrm{Ni}$ volatilization/condensation is a minor process in our conditions. On the one hand, this result could be due to our studied electrode that does not present a specific functionalization with a fine 
microstructure at the interface with the electrolyte (i.e. the cermet does not have a functional layer). On the other hand, this result can also be explained by the duration of our tests that are too short to unambiguously highlight the volatilization as discussed by Holzer et al. [27]. From this point of view, the duration of the long-term tests has to be increased beyond several thousands of hours $(t>10000 \mathrm{~h})$ in order to detect this process as shown by Rinaldi et al. [40] on the same kind of cells.

Opposite to the evaporation/condensation, the local Ni agglomeration appears clearly on the 3D renderings taken in the bulk of the cermet (Fig. 3d-f). The microstructural computations have highlighted that the Ni Particle Size Distribution (PSD) is shifted toward larger particle diameters due to the local sintering of the metallic grains as illustrated on Fig. 4 a for Cell $\mathrm{n}^{\circ} 2$. In other words, there is a clear rearrangement of the smallest particles to the biggest ones for the Ni phase. Moreover, the analyses of the 3D reconstructions have shown that the ceramic backbone remains unaffected by the operation. This statement is illustrated on Fig. $4 \mathrm{~b}$ where the YSZ mean particle diameter is unchanged whatever the duration of the experiments. This expected result confirms the stability of the YSZ phase upon SOFC/SOEC operation, validating the reliability of the reconstructions.

Impact of SOEC vs SOFC operating modes on Ni coarsening - The effect of operating conditions on the microstructural evolution can be analyzed thanks to the set of $3 \mathrm{D}$ reconstructions. In particular, the impact of the cell polarization can be studied from Cells $n^{\circ} 1$ and $n^{\circ} 2$ operated in SOEC mode at $850^{\circ} \mathrm{C}$ with respect to Cell $\mathrm{n}^{\circ} 4$ operated in SOFC mode at the same temperature and absolute value of current densities $\left(\mathrm{i}=+/-0.5 \mathrm{~A} \cdot \mathrm{cm}^{-2}\right.$ : cf. Table I). It is worth reminding that the 3D reconstructions have been extracted from the cell inlet where the steam partial pressure $\left(\mathrm{P}\left(\mathrm{H}_{2} \mathrm{O}\right)=0.5\right)$ is identical. In these conditions, it is found that the growth of the Ni phase follows a typical evolution over time without any specific behavior for the sample operated in fuel cell mode (Fig. 5). Therefore, considering the same conditions of temperature, gas composition and current density, it appears that the higher cell polarization in electrolysis mode does not change the rate of $\mathrm{Ni}$ coarsening. This result points out that the electrode polarization under anodic or cathodic current should not be involved in the sintering mechanism of the Ni particles in the bulk 
of the cermet. Therefore, conversely to the destabilization of the $\mathrm{O}_{2}$ electrode material [43], the ageing of the $\mathrm{H}_{2}$ electrode appears not to be sensitive to the difference of polarization between fuel cell and electrolysis modes. As a consequence, considering our studied cell, the highest degradation rate recorded in electrolysis mode cannot be explained by the Ni coarsening, and could be induced by the $\mathrm{O}_{2}$ electrode deterioration as proposed in [43].

Impact of temperature on Ni coarsening - The impact of the operating temperature is shown in Fig. 5 where the growth of the Ni mean particle diameter upon operation has been plotted for the different tested cells. As previously discussed, a significant agglomeration is found for the cells operated at $850{ }^{\circ} \mathrm{C}$. For instance, an increase in the particle diameters of more than $30 \%$ is measured after $2000 \mathrm{~h}$ of operation. However, as shown in Fig. 5, this evolution is much more limited for the cell tested at $750{ }^{\circ} \mathrm{C}$. In this case, the Ni growth is about $13 \%$ after $9000 \mathrm{~h}$. Therefore, unlike the cell polarization, the temperature is a key parameter affecting the $\mathrm{Ni}$ coarsening. This behavior shows that the Ni coarsening is a thermally activated process related to the local sintering of adjacent metallic particles.

Impact of Ni coarsening on the cermet microstructural properties - The local rearrangement of the Ni particles in the cermet (Fig. 4a) leads to a significant increase of the mean phase diameter (Fig. 5). This morphological evolution is liable to affect other microstructural properties of the electrode. Knowing that the cermet phase volume fractions are not changed upon operation, the other parameters potentially affected by the $\mathrm{Ni}$ coarsening are: (i) the properties related to the gas phase, (ii) the Ni tortuosity factors, (iii) the Ni/YSZ or Ni/gas interfacial surface areas and (iv) the density of TPBls.

For the gas phase, the microstructural analyses have revealed that the local Ni reorganization has a moderate effect on the mean pore radius. For example, the mean diameter is increased from 0.96 $\mu \mathrm{m}$ for the pristine cell to $1.16 \mu \mathrm{m}$ for Cell $\mathrm{n}^{\circ} 2$ after $2000 \mathrm{~h}$ of operation. It can be noticed that this evolution is in good agreement with the results reported by Khan et al. [26]. As expected, the Ni coarsening is accompanied with a noticeable increase of the tortuosity factor for the metallic phase. For instance, it is changed from 7.45 for the pristine sample to 8.27 for Cell $\mathrm{n}^{\circ} 2$. This evolution 
can be easily explained since the growth of the largest particles is done to the detriment of the smallest ones. This rearrangement decreases the number and the section area of necks between the particles. In the most severe case, the phenomenon can induce the particles disconnection in the network, and thus cause the loss of the phase percolation as reported in Costamagna et al. [59] and Iwanschitz et al. [60]. This evolution should affect both the geometrical tortuosity and the phase constrictivity [50] in such a way that the resulting "apparent" tortuosity factor will be increased. However, in practice, this modification is limited so that the effective electronic conductivity of Nickel and the electrode performances are not impacted by this modification as already discussed in Lay-Grindler et al. [17].

Based on a sintering process, the Ni coarsening is also concomitant with a reduction of its specific surface area. However, it has been found that the repartition of the decrease between the interfacial surface areas of $\mathrm{Ni} /$ gas and $\mathrm{Ni} / \mathrm{YSZ}$ is not the same. This difference is shown in Fig. 6 where the evolution of the interfacial specific surface area between Ni and YSZ is compared with the one between $\mathrm{Ni}$ and gas for the cells tested at $850{ }^{\circ} \mathrm{C}$. While the $\mathrm{Ni} / \mathrm{YSZ}$ specific surface area remains stable over time, the $\mathrm{Ni} /$ gas specific surface area decreases strongly. This statement means that the $\mathrm{Ni}$ agglomeration in the cermet mainly originates from the rearrangement of the surface in contact with the gas whereas the particles are strongly attached to the YSZ backbone. Indeed, the energy related to the adhesion of $\mathrm{Ni}$ onto $\mathrm{YSZ}$ is expected to be much higher than free surface energy for the metal [61]. This behavior is likely to prevent the massive Ni sintering at the SOFC/SOEC operating temperature, and could explain why the coarsening tends to slow down rapidly with time. This inhibition effect of the YSZ network on the Nickel agglomeration has been proposed by many authors [62-65]. The precise analysis of the microstructural properties obtained by X-ray nanotomography allowed highlighting the crucial role of the YSZ backbone on the Ni sintering in the cermet.

Finally, it is known that Ni coarsening induces a significant loss of active TPBls. In the present work, the microstructural computations on the reconstructed volumes have revealed a substantial decrease at $850{ }^{\circ} \mathrm{C}$ (Fig. 7a) which appears to be far more limited at $750{ }^{\circ} \mathrm{C}$ (Fig. 7b). For instance, the decrease of electrochemically active sites in the $\mathrm{H}_{2}$ electrode is about $30 \%$ after 2000 hours at 
$850{ }^{\circ} \mathrm{C}$ whereas the decline is limited to $12 \%$ after 9000 hours at $750{ }^{\circ} \mathrm{C}$. The microstructural changes in the cermet are liable to have a strong influence on the cell performances.

\section{Discussion: Impact of Ni coarsening on cell performances}

\subsection{Ni agglomeration modelling}

In order to assess the impact of $\mathrm{Ni}$ coarsening on cell performances, the evolution of the Ni particle diameter upon operation has to be modelled. Several kinetic laws have been proposed in the literature to calculate the grain-size growth in the cermet. A first phenomenological approach is based on geometrical considerations of spheres agglomeration [19,21,25,34]. A second approach uses physically-based models for the sintering of two adjacent particles [15,19,26,31,35,36,42,65]. In this frame, a mechanism based on a kind of Ostwald ripening process should be relevant to compute the local Ni agglomeration in the cermet. Indeed, this model describes the sintering stage for which the driving force is the reduction of the free surface energy with a mass transfer from small to larger particles (as experimentally highlighted in Fig. 4a. for the Ni particle rearrangement and in Fig. 6 for the decease of the Ni free surface). Based on this assumption, the kinetic rate can be expressed through a standard power-law equation of the following general form [66]:

$$
d_{N i}(t)=\left[k_{\text {pow }}^{d_{N i} \times t}+\left[d_{N i}(t=0)\right]^{n}\right]^{1 / n} \text { with } \quad k_{\text {pow }}^{d_{N i}=k_{00} \times e^{\frac{-E a}{R T}}}
$$

where $t$ is the time and $d_{N i}$ denotes the Ni mean particle diameter. The term $k_{\text {pow }}^{d_{N i}}$ is the rate constant of the thermally activated process. It is expressed according to an Arrhenius law where $E_{a}$ is the activation energy, $k_{00}$ the pre-exponential factor and $R$ the gas constant. The exponent $n$ is characteristic of the predominant mass transport involved in the sintering process. A low exponent value corresponds to a local evaporation-condensation process whereas higher values are related to surface or bulk solid-state diffusion for agglomeration [67,68].

In order to improve the quality of the fitting, the data set has been complemented by other values collected from the literature for a similar cermet $[25,62]$. As shown in Fig. 5, the data from Tanasini et al. [25] obtained at $850{ }^{\circ} \mathrm{C}$ on the same cells that the ones used in the present work are found to be in perfect line with our measurements. The good agreement between the two sets of data 
obtained by two different research groups who used different techniques proves the reliability of the long-term tests, the post-test characterizations and the microstructural analyses. It can be seen in Fig. 5 that the power law model is able to fit accurately the experimental points. For each temperature, the best adjustment was obtained for an exponent equal to $n=8$. The temperature dependence was fitted with an activation energy of $\mathrm{Ea}=204.36 \mathrm{~kJ}^{\mathrm{mol}}{ }^{-1}$. It can be noticed that this value is good accordance with the data reported in the literature [41,42]. The high value for $n$ is consistent with a surface diffusion mechanism for coarsening [68]. Besides, it could be also related to the inhibiting effect of the YSZ backbone on the Nickel agglomeration. Indeed, an increase of $n$ reinforces the asymptotic behavior of the model for which the Ni particle size tends toward an upper bound for very long operating time.

Even if fewer studies have been dedicated to the loss of electroactive sites upon operation, it has been shown that the evolution of TPBls over the time can be modelled with a kinetic law that follows the same general form than the one related to the Ni grain-size growth $[19,26,42,69]$. For example, Faes et al. [19] have adapted the so-called "unloading capacitor" model for the Ni grainsize growth into an equivalent expression to simulate the decrease of TPBls. In the present work, the power-law model given in Eq. (1) has been modified in order to describe the decrease in the density of TPBls upon operation:

$$
\xi_{T P B}(t)=2 \times \xi_{T P B}(t=0)-\left[k_{p o w}^{\xi_{T P B}} \times t+\left(\xi_{T P B}(t=0)\right)^{n}\right]^{1 / n}
$$

where $\xi_{T P B}$ denotes the density of active TPBls and $k_{\text {pow }}^{\xi_{T P B}}$ is a kinetic parameter fitted on the experimental data. It can be seen in Fig. $7 \mathrm{a}$ and $7 \mathrm{~b}$ that the law is able to simulate the decrease in the density of TPBls with the same exponent than the one use for the Ni particle size increase (i.e. $n=8$ ). However, it is worth noting that Eq. (2) is purely phenomenological. Other expressions could be obtained by introducing the power model in the microstructural correlations that link the density of TPB1s to the geometrical attributes of the electrode [70-73]. The relevance of such geometrical modelling approach to predict the loss of TPBls due to Ni agglomeration will be assessed in a future work [74].

The TPBls being the electrochemical active sites in the $\mathrm{H}_{2}$ electrode, it is expected that their significant decrease will affect the performances. This potential electrode degradation due to the Ni coarsening is quantified by using a modelling approach in the next section. 
4.2 Quantification of Ni coarsening on the degradation

Impact of Ni coarsening on the cell performances - An in-house multi-scale modelling has been used to simulate the effect of $\mathrm{Ni}$ agglomeration on the cell performances. The numerical tool is constituted by two 'micro-scale' models [75,76] developed for each electrode combined with a 'macroscopic' module describing the cell operation under SOFC [77] or SOEC mode [78]. A detailed description of the model architecture as well as all the input parameters requested for the cell simulations have been already published in [43]. Therefore, only a brief description of the model is provided hereafter.

At the cell level, the 'macroscopic' model describes the radial co-flow configuration of the test bench. It allows the local current density, the gas composition, the ohmic losses and the activation and concentration overpotentials to be computed along the cell radius. The exchange current densities needed to calculate the activation overpotentials at the 'macroscopic' scale are calculated at the 'microscopic' level through the electrode models depending on the local partial pressures used as boundary conditions. In this framework, the electrode models include the description of the mass and charge transport in the gas, ionic and electronic phases as well as the reaction processes occurring therein. For the $\mathrm{H}_{2}$ electrode, the mechanism is limited to a simple charge transfer at TPBls [75] whereas a more complex reaction pathway has been implemented for the $\mathrm{O}_{2}$ electrode [76]. It is worth noting that the equations for mass and charge transfers and the expressions for the reactions kinetic rates depend on the microstructural properties computed on the $3 \mathrm{D}$ reconstructions. In particular, the rate for the reaction of $\mathrm{H}_{2}$ electro-oxidation (or $\mathrm{H}_{2} \mathrm{O}$ electro-reduction) in the Ni-YSZ cermet is directly proportional to the density of active TPBls [66]. Finally, as already mentioned in [43], it can be noticed that the models for both $\mathrm{H}_{2}$ and $\mathrm{O}_{2}$ electrodes have been specifically adapted to describe the structure of the Ni-YSZ cermet and LSCF-CGO/LSCF bilayer of the studied cell.

As shown in Fig. 1, an excellent agreement is found between the experimental i-V curves and the simulated performances of the pristine cell at $800{ }^{\circ} \mathrm{C}$ and $850^{\circ} \mathrm{C}$ in SOFC and SOEC modes. As a consequence, the model is able to simulate accurately the experimental polarization curves in 
different operating modes. It can thus be considered as being validated to investigate the impact of Ni coarsening on cell performances.

In order to calculate the effect of $\mathrm{Ni}$ agglomeration on the cell response, Eq. (2) describing the loss of active TPBls has been implemented in the model. In parallel, it has been checked that the increase of the Ni tortuosity factor does not change significantly the cell response in such a way that it can be neglected for the simulations. Once the model upgraded with Eq. (2), the cell performances have been computed upon operation in the conditions of the cell ageing for Cells $\mathrm{n}^{\circ} 1,2$ and 4 (i.e. with a ratio of $\mathrm{H}_{2} / \mathrm{H}_{2} \mathrm{O}=50 / 50$ at $850{ }^{\circ} \mathrm{C}$ and a current density of $+/-0.5$ A.cm ${ }^{-2}$ in SOFC or SOEC mode cf. Table I).

The computed cell voltage degradation induced by the Ni coarsening has been plotted as a function of time in fuel cell and electrolysis modes in Fig. 8a and Fig. 8b, respectively. After $2000 \mathrm{~h}$ of operation, the calculated voltage loss is around $2 \mathrm{mV}$ in fuel cell condition and $3.5 \mathrm{mV}$ under electrolysis current. In this case, the difference in cell degradation between the two modes is simply attributed to the higher activation overpotentials for the $\mathrm{H}_{2}$ electrode when operated under electrolysis condition [79].

The simulated evolution of cell voltage due to the $\mathrm{Ni}$ agglomeration has been also compared to the experimental degradation rates in Fig. $8 \mathrm{a}$ and $8 \mathrm{~b}$. It is found that the Ni agglomeration explains about $30 \%$ of the cell voltage decrease after 1000 hours of operation in fuel cell mode (Fig. 8a). This observation is consistent with the result of Faes et al. [19], who have reported for stacks tested in fuel cell mode over more than $1000 \mathrm{~h}$ that the "anode degradation is responsible for $18 \%$ to $41 \%$ of the total degradation". Nevertheless, as shown in Fig. $8 \mathrm{~b}$ under electrolysis operation, the percentage of the cell voltage degradation ascribed to the Ni coarsening decreases to $20-25 \%$ after 1000-2000 $\mathrm{h}$. This trend is obviously explained since the experimental degradation rates are three times higher in electrolysis mode compared to the fuel cell condition (Table II and Fig. 8). As a consequence, in spite of a substantial contribution of $\mathrm{Ni}$ agglomeration, the microstructural change in the cermet does not explain the highest losses in cell performances under electrolysis current. From this point of view, other important mechanisms must be involved in the degradation especially under SOEC mode. This observation reinforces the assumption that the destabilization 
of the $\mathrm{O}_{2}$ electrode and its reactivity with the electrolyte could be a major process to account for the acceleration of the cell degradation when operated under electrolysis current [35]. Finally, it is worth reminding that the present study has been carried out by keeping the same gas composition for the fuel cell and electrolysis tests (i.e. $\mathrm{H}_{2} / \mathrm{H}_{2} \mathrm{O}=50 / 50$ ). This particular operating condition was chosen for a direct comparison of the degradation rates between the fuel cell and the electrolysis experiments. However, for a commercial reversible application, the cell will be fed under dry hydrogen for fuel cell operation whereas a high steam content will be used in electrolysis. For example, a ratio $\mathrm{H}_{2} / \mathrm{H}_{2} \mathrm{O}$ of $10 / 90$ is used in [40] to test a commercial short-stack in electrolysis mode. In this case, the higher steam partial pressure in the gas stream should also participate to the degradation by promoting the Ni volatilization for example [27].

Effect of temperature on the cell degradation assessment - As already observed by other authors $[39,56,57]$, it has been highlighted that the voltage loss recorded during the long term test at $750{ }^{\circ} \mathrm{C}$ is higher than the one recorded for the test performed at $850{ }^{\circ} \mathrm{C}$ for the same condition of current density and operating mode (i.e. in fuel cell mode at $\mathrm{i}=+0.5 \mathrm{~A}_{\mathrm{cm}} \mathrm{cm}^{-2}$ : cf. Table II for Cell $\mathrm{n}^{\circ} 4$ and $\mathrm{n}^{\circ} 5$ ). This statement is inconsistent with the thermally activated behavior of the Ni coarsening. Indeed, as shown in Fig. 7, the decrease in the TPBls density is lower at $750{ }^{\circ} \mathrm{C}$ than $850{ }^{\circ} \mathrm{C}$. Therefore, the unexpected dependence of the voltage loss with temperature could be explained by other degradation phenomena. In this case, the degradation mechanisms must be dependent on the level of electrode overpotential. Indeed, for the same current density, the electrode overpotential is higher at $750{ }^{\circ} \mathrm{C}$ than $850{ }^{\circ} \mathrm{C}$.

Nevertheless, it is worth noting that the temperature at which the voltage loss is measured after the ageing test could potentially introduce a bias in the assessment of the degradation rates. Therefore, the model has been employed to evaluate the role of the temperature, denoted $T_{\text {charact }}$, chosen to assess the cell voltage loss after a long-term operation performed in steady-state condition at another temperature, denoted $T_{\text {operation. }}$. As an illustration, the degradation has been simulated for an ageing over a period of $10000 \mathrm{~h}$ in the operating condition of Cell $\mathrm{n}^{\circ} 4$ at $T_{\text {operation }}=850^{\circ} \mathrm{C}$ and

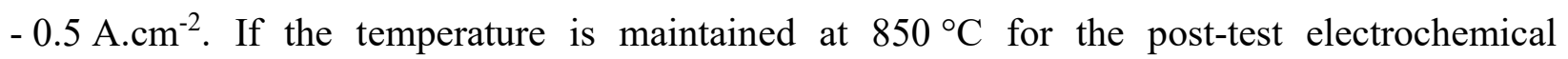
characterization (i.e. $T_{\text {charact }}=850^{\circ} \mathrm{C}$ ), the cell voltage loss is calculated to be $10 \mathrm{mV}$ at $-0.5 \mathrm{~A} . \mathrm{cm}^{-2}$. However, if the temperature is decreased for the characterization to $T_{\text {charact }}=750^{\circ} \mathrm{C}$, the computed voltage loss at the same current density is increased to $25 \mathrm{mV}$. In other words, the degradation due 
to the $\mathrm{Ni}$ coarsening is higher if assessed at lower temperature. This result is related to the thermally-activated behavior of the electrode activation overpotential. For a given deterioration of the electrode material, its impact on the activation overpotential is thus enhanced at lower temperature. This remark means that the degradation rates should be evaluated at the same temperature after the durability experiments to be compared to each other. Therefore, it appears that the degradation rate measured at $750{ }^{\circ} \mathrm{C}$ for Cell $\mathrm{n}^{\circ} 5$ cannot be directly compared to rate measured at $850{ }^{\circ} \mathrm{C}$ for Cell $n^{\circ} 4$. In other words, the higher degradation rate obtained for Cell $n^{\circ} 5$ does not necessarily indicate a higher cell deterioration. This remark could potentially explain our surprising results between Cell $n^{\circ} 4$ and $n^{\circ} 5$ as well as the ones reported in literature on the effect of the operating temperature on the degradation $[39,56,57]$.

\section{Conclusion}

A series of long-term experiments $(1000 \mathrm{~h} \leq t \leq 9000 \mathrm{~h})$ have been carried out with typical SOCs in order to investigate the impact of $\mathrm{Ni}$ coarsening on the global cell performances. The durability tests have been performed in galvanostatic condition under fuel cell or electrolysis current at $850^{\circ} \mathrm{C}$ and $750^{\circ} \mathrm{C}$. For equivalent operating conditions (i.e. considering the same temperature, inlet gas composition and current densities at $+/-0.5 \mathrm{~A} \cdot \mathrm{cm}^{-2}$ ), it has been found that the degradation rates are higher in electrolysis than in fuel cell mode. Moreover, it has been highlighted that the voltage loss upon fuel cell operation is decreased with increasing the operating temperature.

Observations of the tested cells have been conducted on polished cross-sections with a highresolution SEM. The post-mortem characterizations have revealed a substantial Ni coarsening whereas, in our testing conditions, the Ni depletion at the electrolyte interface seems to be very limited. In order to confirm these results, three-dimensional reconstructions of the Ni-YSZ cermet have been obtained by synchrotron X-ray nanotomography for the pristine and operated cells. Evolution of the microstructural properties due to the Ni agglomeration have been quantified on the reconstructed volumes taken in the bulk of the $\mathrm{H}_{2}$ electrode. 
The microstructural analyses have shown that the Ni volume fraction remains unaffected by the operation confirming that the Ni volatilization followed by its condensation is very limited in our experimental conditions. Nevertheless, the $\mathrm{Ni}$ phase size distribution is shifted towards bigger particle diameters indicating a significant Ni coarsening upon operation. As expected, the process is associated to a significant loss of active TPBls. It is also correlated with a strong decrease of the $\mathrm{Ni}$ /gas specific surface area, while the one between Ni and YSZ is not changed upon operation. This result points out that the ceramic backbone limits the Ni sintering in the cermet preventing any massive $\mathrm{Ni}$ agglomeration to occur in operation. When considering similar conditions of steam partial pressure and current density, the rate of $\mathrm{Ni}$ coarsening is independent on the $\mathrm{H}_{2}$ electrode polarization in fuel cell or electrolysis mode. However, the growth of the Ni particle size is thermally activated resulting in a higher material ageing at higher temperature.

In order to simulate the Ni agglomeration, a classical power-law sintering model has been adjusted on the evolution of the mean particle size and density of TPBls. A rather high exponent $(n=8)$ was necessary to fit accurately the evolution of the microstructural parameters. This value reflects the inhibiting effect of the YSZ backbone on the Ni sintering and could be consistent with a mechanism controlled by surface diffusion. The adjusted law describing the TPBls decrease over the time has been implemented in an in-house multi-scale modelling framework to compute the loss in cell performances. The simulations have shown that the microstructural change in the $\mathrm{H}_{2}$ electrode explains about $30 \%$ of the total degradation in fuel cell mode and about $20-25 \%$ in electrolysis mode at $850{ }^{\circ} \mathrm{C}$ after 1000-2000 h. Moreover, thanks to the modelling approach, it has been highlighted that the temperature at which the degradation is measured after the durability experiment plays a major role on the result. This could potentially explain the unexpected lower degradation rates obtained at $850^{\circ} \mathrm{C}$ compared to the one observed at $750{ }^{\circ} \mathrm{C}$. 


\section{Acknowledgments}

The research leading to these results has received funding from the European Union's Seventh Framework Programme (FP7/2007-2013) Fuel Cells and Hydrogen Joint Undertaking (FCH-JU2013-1) under grant agreement $n^{\circ} 621173$ (SOPHIA project) and grant agreement $n^{\circ} 621207$ (ENDURANCE project). The work has also been supported by European Horizon 2020 - Research and Innovation Framework Programme (H2020-JTI-FCH-2015-1) under grant agreement $\mathrm{n}^{\circ}$ 735918 (INSIGHT project). 


\section{Nomenclature}

Abbreviations

CGO Ceria doped Gadolinium Oxide

FIB Focused Ion Beam

FU Fuel Utilization rate. It is defined as the conversion rate of hydrogen into steam. $F U=\left|n_{\mathrm{H}_{2}}^{\text {outlet }}-n_{\mathrm{H}_{2}}^{\text {inlet }}\right| / n_{\mathrm{H}_{2}}^{\text {inlet }}$

LSC Lanthanum Strontium Cobaltite

LSCF Lanthanum Strontium Cobalt Ferrite

OCV Open Circuit Voltage

PSD Particle Size Distribution

SC Steam Conversion rate. It is defined as the conversion rate of steam into hydrogen. $S C=\left|n_{H_{2}}^{\text {outlet }}-n_{\mathrm{H}_{2}}^{\text {inlet }}\right| / n_{\mathrm{H}_{2} \mathrm{O}}^{\text {inlet }}$

SE Secondary Electrons

SEM Scanning Electron Microscopy

SOEC Solid Oxide Electrolysis Cell

SOFC Solid Oxide Fuel Cell

TPBls Triple Phase Boundary lengths

YSZ Yttria Stabilized Zirconia

List of symbols

$d_{N i} \quad$ Ni mean particle diameter, $\mu \mathrm{m}$

$E_{a} \quad$ Activation energy, J.mol ${ }^{-1}$

$k_{\text {pow }}^{d_{N i}} \quad$ Rate constant of Ni agglomeration process

$k_{\text {pow }}^{\xi_{T P B}} \quad$ Rate constant of the TPBls density evolution process

$k_{00} \quad$ Pre-exponential factor in the Arrhenius law of $k_{\text {pow }}^{d_{N i}}$

$R \quad$ Gas constant, 8.314 J.mol ${ }^{-1} \cdot \mathrm{K}^{-1}$

$T_{\text {operation }} \quad$ Temperature at which the cell is aged, ${ }^{\circ} \mathrm{C}$

$T_{\text {charact }} \quad$ Temperature at which the cell is characterised, ${ }^{\circ} \mathrm{C}$

$\xi_{T P B} \quad$ Density of active TPBls, $\mu \mathrm{m}^{-2}$ 


\section{References}

[1] V. Subramani, A. Basile, T.N. Veziroglu, Compendium of hydrogen energy, Volume 1: Hydrogen production and purification, Elsevier, Woohhead Publishing, 2015.

[2] A. Godula-Jopek, "Hydrogen Production by Electrolysis", Wiley, 2015.

[3] S.C. Singhal and K. Kendall, "High Temperature Solide Oxide Fuel cells, Fundamental, Design and Applications", Elsevier, 2003.

[4] K. Huang, J. B. Goodenough, "Solid oxide fuel cell technology: principles, performance and operations", Elsevier, (2009).

[5] J. Kupecki, ed. "Modeling, Design, Construction, and Operation of Power Generators with Solid Oxide Fuel Cells: From Single Cell to Complete Power System”, Springer, (2018).

[6] A. Hauch, D. Ebbensen, S.H. Jensen, M. Mogensen, J. Electrochem. Soc., 155(11) (2008) B1284-B1193.

[7] J. Schefold, A. Brisse, F. Tietz, J. Electrochem. Soc., 159(2) (2012) A137-A144.

[8] P. Hjalmarsson, X. Sun, Y.-L. Liu, Ming Chen, J. Power Sources, 262 (2014) 316-322.

[9] T.L. Skafte, J. Hjelm, P. Blennow, C. Graves, "Quantitative review of degradation and lifetime of solid oxide cells and stacks", in: $12^{\text {th }}$ European SOFC \& SOE Forum, B0501, Lucerne, Switzerland, 2016.

[10] H. Yokokawa, H. Tu, B. Iwanschitz, Andreas Mai, Fundamental mechanisms limiting solid oxide fuel cell durability, J. Power Sources, 182 (2008) 400-412.

[11] K. Chen, S.P. Jiang, Review - Materials degradation of solid oxide electrolysis cells, J. Electrochem. Soc., 163(11) (2016) F3070-F3083.

[12] H. Madi, A. Lanzini, S. Diethelm, D. Papurello, J. Van herle, M. Lualdi, J. G. Larsen, Massimo Santarelli, "Solid oxide fuel cell anode degradation by the effect of siloxanes" Journal of Power Sources 279 (2015) 460-471.

[13] H. Madi, A. Lanzini, D. Papurello, S. Diethelm, C. Ludwig, M. Santarelli, J. Van herle, "Solid oxide fuel cell anode degradation by the effect of hydrogen chloride in stack and single cell environments" Journal of Power Sources 326 (2016) 349-356.

[14] D. Papurello, A. Lanzini, S. Fiorilli, F. Smeacetto, R. Singh, M. Santarelli, "Sulfur poisoning in Ni-anode solid oxide fuel cells (SOFCs): deactivation in single cells and a stack" Chemical Engineering Journal 283 (2016) 1224-1233.

[15] D. Simwonis, F. Tietz, D. Stover, Solid State Ionics 132 (2000) 241-251.

[16] Z. Jiao, N. Shikazono, N. Kasagi, Quantitative Characterization of SOFC Nickel-YSZ Anode Microstructure Degradation Based on Focused-Ion-Beam 3D-Reconstruction Technique, J. Electrochem. Soc., 159 (3) (2012) B285-B291.

[17] E. Lay-Grindler, J. Laurencin, J. Villanova, P. Cloetens, P. Bleuet, A. Mansuy, J. Mougin, G. Delette, Journal of Power Sources, 269 (2014) 927-936.

[18] A. Zekri, M. Knipper, J. Parisi, T. Plaggenborg, "Microstructure degradation of Ni/CGO anodes for solid oxide fuel cells after long operation time using 3D reconstructions by FIB tomography", Physical Chemistry Chemical Physics 19 (21) (2017) 13767-13777.

[19] A. Faes, A. Hessler-Wyser, D. Presvytes, C. G. Vayenas, Nickel-zirconia anode degradation and triple phase boundary quantification from microstructural analysis, Fuel cells 9(6) (2009) 841851. 
[20] Q. Li, L. Liang, K. Gerdes, L.-Q. Chen, "Phase-field modeling of three-phase electrode microstructures in solid oxide fuel cells", Applied Physics Letters 101 (3) (2012) 033909.

[21] G. J. Nelson, K. N. Grew, J. R. Izzo, J. J. Lombardo, W. M. Harris, A. Faes, A. HesslerWyser, J. Van herle, S. Wang, Y. S. Chu, A. V. Virkar, W. K. Chiu, Three-dimensional microstructural changes in the Ni-YSZ solid oxide fuel cell anode during operation, Acta Materialia, 60(8) (2012) 3491-3500.

[22] G. Brus, H. Iwai, A. Sciazko, M. Saito, H. Yoshida, J.S. Szmyd, Local evolution of anode microstructure morphology in solid oxide fuel cell after long-term stack operation, J. Power Sources, 288 (2015) 199-205.

[23] T. Matsui, R. Kishida, J.H. Kim, H. Muroyama, K. Eguchi, Performance deterioration of NiYSZ anode induced by electrochemically generated steam in solid oxide fuel cells, J. Electrochem. Soc., 157(5) (2010) B776-B781.

[24] T. Matsui, R. Kishida, H. Muroyama, K. Eguchi, "Comparative Study on Performance Stability of Ni-Oxide Cermet Anodes under Humidified Atmospheres in Solid Oxide Fuel Cells", Journal of The Electrochemical Society 159(8) (2012) F456-F460.

[25] P. Tanasini, M. Cannarozzo, P. Costamagna, A. Faes, J. Van Herle, A. Hessler-Wyser, C. Comninellis, Experimental and theoretical investigation of degradation mechanisms by particle coarsening in SOFC electrodes, Fuel Cells, 9(5) (2009) 740-752.

[26] M. Z. Khan, M. T. Mehran, R.-H. Song, J.-W. Lee, S.-B. Lee, T.-H. Lim, "A simplified approach to predict performance degradation of a solid oxide fuel cell anode", Journal of Power Sources 391 (2018) 94-105.

[27] L. Holzer, B. Iwanschitz, T. Hocker, B. Münch, M. Prestat, D. Wiedenmann, U. Vogt, P. Holtappels, J. Sfeir, A. Mai, T. Graule, Microstructure degradation of cermet anodes for solid oxide fuel cells: Quantification of nickel grain growth in dry and in humid atmospheres, Journal of Power Sources, 196(3) (2011) 1279-1294.

[28] J.S. Cronin, J.R. Wilson, S.A. Barnett, Impact of pore microstructure evolution on polarization resistance of Ni-Yttria-stabilized zirconia fuel cell anodes, J. Power Sources, 196(5) (2011) 2640-2643.

[29] Y. H. Lee, H. Muroyama, T. Matsui, K. Eguchi, Degradation of nickel-yttria-stabilized zirconia anode in solid oxide fuel cells under changing temperature and humidity conditions, J. Power Sources, 262 (2014) 451-456.

[30] H. Y. Chen, H. C. Yu, J. S. Cronin, J. R. Wilson, S. A. Barnett, K. Thornton, Simulation of coarsening in three-phase solid oxide fuel cell anodes, J. Power Sources, 196(3) (2011) 1333-1337. [31] R. Vaßen, D. Simwonis, D. Stöver, Modelling of the agglomeration of Ni-particles in anodes of solid oxide fuel cells, Journal of Materials Science, 36(1) (2001) 147-151.

[32] Jens Sehested, Four challenges for nickel steam-reforming catalysts, Catalysis Today 111 (2006) 103-110.

[33] Z. Jiao, N. Takagi, N. Shikazono, N. Kasagi, Study on local morphological changes of nickel in solid oxide fuel cell anode using porous Ni pellet electrode, J. Power Sources, 196(3) (2011) 1019-1029.

[34] S. Gao, J. Li, Z. Lin, Theoretical model for surface diffusion driven Ni-particle agglomeration in anode of solid oxide fuel cell, J. Power Sources, 255 (2014) 144-150.

[35] J. Mason, I. Celik, S. Lee, H. Abernathy, G. Hackett, "Performance Degradation Predictions Based on Microstructural Evolution Due to Grain Coarsening Effects in Solid Oxide Fuel Cell Electrodes", Journal of The Electrochemical Society 165 (2) (2018) F64-F74. 
[36] L. KröllL. G. J. de Haart, I. Vinke, R-A. Eichel, "Degradation Mechanisms in Solid-Oxide Fuel and Electrolyzer Cells: Analytical Description of Nickel Agglomeration in a Ni/Y S Z Electrode", Physical Review Applied 7 (4) (2017) 044007.

[37] A. Hauch, M. Mogensen, A. Hagen, Ni/YSZ electrode degradation studied by impedance spectroscopy-Effect of p (H2O), Solid State Ionics 192 (1) (2011) 547-551.

[38] M.B. Mogensen, A. Hauch, X. Sun, M. Chen, Y. Tao, S.D. Ebbesen, K.V. Hansen, P.V. Hendriksen, Relation between Ni particle shape change and Ni migration in Ni-YSZ electrodes-A hypothesis, Fuel Cells, 17 (4) (2017) 434-441.

[39] A. Hagen, R. Barfod, P. V. Hendriksen, Y.-L. Liu, S. Ramousse, Degradation of anode supported SOFCs as a function of temperature and current load, J. Electrochem. Society, 153(6) (2006) A1165-A1171.

[40] G. Rinaldi, S. Diethelm, E. Oveisi, P. Burdet, J. Van herle, D. Montinaro, Q. Fu, A. Brisse, Post-test analysis on a solid oxide cell stack operated for 10700 hours in steam electrolysis mode, Fuel Cells, 17 (2017) 541-549.

[41] J. Sehested, J. AP Gelten, S. Helveg, "Sintering of nickel catalysts: Effects of time, atmosphere, temperature, nickel-carrier interactions, and dopants", Applied Catalysis A: General 309(2) (2006) 237-246.

[42] D. Kennouche, Y. K. Chen-Wiegart, C. Riscoe, J. Wang, S. A. Barnett, "Combined electrochemical and X-ray tomography study of the high temperature evolution of Nickel-Yttria Stabilized Zirconia solid oxide fuel cell anodes", Journal of Power Sources 307 (2016) 604-612 [43] J. Laurencin, M. Hubert, D. Ferreira Sanchez, S. Pylypko, M. Morales, A. Morata, B. Morel, D. Montinaro, F. Lefebvre-Joud, E. Siebert, Degradation mechanism of $\mathrm{La}_{0.6} \mathrm{Sr}_{0.4} \mathrm{Co}_{0.2} \mathrm{Fe}_{0.8} \mathrm{O}_{3-}$ ${ }_{\delta} / \mathrm{Gd}_{0.1} \mathrm{Ce}_{0.9} \mathrm{O}_{2-\delta}$ composite electrode operated under solid oxide electrolysis and fuel cell conditions, Electrochimica Acta, 241 (2017) 459-476.

[44] J. C. Da Silva, A. Pacureanu, Y. Yang, S. Bohic, C. Morawe, R. Barrett, P. Cloetens, Efficient concentration of high-energy x-rays for diffraction-limited imaging resolution, Optica, 4(5) (2017) 492-495.

[45] R. Mokso, P. Cloetens, E. Maire, W. Ludwig, J-Y. Buffière, Nanoscale zoom tomography with hard x rays using Kirkpatrick-Baez optics, Applied physics letters, 90(14) (2007) 144104 13.

[46] M. Hubert, A. Pacureanu, C. Guilloud, Y. Yang, J. C. da Silva, J. Laurencin, F. LefebvreJoud, P. Cloetens Efficient correction of wavefront inhomogeneities in X-ray holographic nanotomography by random sample displacement, Applied Physics Letters 112(20) (2018) 203704 [47] R.N. Bracewell, A.C. Riddle, Inversion of Fan-Beam Scans in Radio Astronomy, The Astrophysical Journal, 150 (1967) 427-434.

[48] J. Villanova, J. Laurencin, P. Cloetens, P. Bleuet, G. Delette, H. Suhonen, F. Usseglio-Viretta, 3D phase mapping of SOFC YSZ/Ni cermet at the nanoscale by X-Ray holotomography, J. Power Sources, 243 (2013) 841-849.

[49] M. Hubert, J. Laurencin, P. Cloetens, J. C. Da Silva, F. Lefebvre-Joud, P. Bleuet, A. Nakajo, E. Siebert, Role of microstructure on electrode operating mechanisms for mixed ionic electronic conductors: From synchrotron-based 3D reconstruction to electrochemical modeling, Solid State Ionics, 294 (2016) 90-107. 
[50] H. Moussaoui, J. Laurencin, Y. Gavet, G. Delette, M. Hubert, P. Cloetens, T. Le Bihan, J. Debayle, Stochastic Geometrical Modeling of Solid Oxide Cells Electrodes Validated on 3D Reconstructions, Computational Materials Science, 143 (2018) 262-276.

[51] F. Usseglio-Viretta, J. Laurencin, G. Delette, J. Villanova, P. Cloetens, Quantitative microstructure characterization of a Ni-YSZ bi-layer coupled with simulated cathode polarisation, J. Power Sources, 256 (2014) 394-403.

[52] J. Laurencin, R. Quey, G. Delette, H. Suhonen, P. Cloetens, P. Bleuet, Characterisation of SOFC Ni-8YSZ substrate by synchrotron X-ray nano-tomography. From 3D reconstruction to microstructure quantification, J. Power Sources 198 (2012) 182-189.

[53] Z. Wuillemin, S. Ceschini, Y. Antonetti, C. Beetschen, S. Modena, D. Montinaro, T. Cornu, O. Bucheli, M. Bertoldi, "High-performance SOFC stacks tested under different reformate compositions", 11 th European SOFC \& SOE Forum Lucerne (2014) A0901

[54] B. Morel, B. Sommacal, F. Lefebvre-Joud, Towards local high fuel utilization diagnosis in SOFCs: experimental approach, in: 5th International Conference on Fundamentals \& Development of Fuel Cell, Karlsruhe, Germany, (2013).

[55] H. Orui, K. Nozawa, K. Watanabe, S. Sugita, R. Chiba, T. Komatsu, H. Arai, M. Arakawa, "Development of practical size anode-supported solid oxide fuel cells with multilayer anode structures", Journal of The Electrochemical Society 155 (11) (2008) B1110-B1116.

[56] S. Diethelm, J. Van Herle, D. Montinaro, O. Bucheli, "Electrolysis and Co-Electrolysis Performance of SOE Short Stacks", Fuel Cells 13(4) (2013) 631-637

[57] Q. Fang, L. Blum, N. H. Menzler, "Performance and Degradation of Solid Oxide Electrolysis Cells in Stack", Journal of The Electrochemical Society 162(8) (2015) F907-F912

[58] Q. Fang, C. E. Frey, N. H. Menzler, L. Blum, "Electrochemical Performance and Preliminary Post-Mortem Analysis of a Solid Oxide Cell Stack with 20,000 h of Operation", Journal of The Electrochemical Society 165 (2) (2018) F38-F45.

[59] P. Costamagna, P. Costa, V. Antonucci, Electrochim. Acta 43 (3-4) (1998) 375-394.

[60] B. Iwanschitz, J. Sfeir, A. Mai, M. Schütze, J. Electrochem. Soc. 157 (2) (2010) B269-B278.

[61] M.C. Muñoz, S. Gallego, J.I. Beltrán, J. Cerdá, Adhesion at metal- $\mathrm{ZrO}_{2}$ interfaces, Surface Science Reports 61 (2006) 303-344.

[62] S. P. Jiang, "Sintering behavior of Ni/Y2O3-ZrO2cermet electrodes of solid oxide fuel cells", Journal of materials science 38 (18) (2003) 3775-3782.

[63] H. Tu, U. Stimming, "Advances, aging mechanisms and lifetime in solid-oxide fuel cells", Journal of Power Sources 127(1) (2004) 284-293.

[64] L. Jia, Z. Lu, J. Miao, Z. Liu, G. Li, W. Su, "Effects of pre-calcined YSZ powders at different temperatures on Ni-YSZ anodes for SOFC", Journal of alloys and compounds 414(1) (2006) 152157.

[65] M. H. Pihlatie, A. Kaiser, M. Mogensen, M. Chen, "Electrical conductivity of Ni-YSZ composites: Degradation due to Ni particle growth", Solid State Ionics 189(1) (2011) 82-90.

[66] H. Fischmeister, G. Grimvall, Ostwald ripening - A survey, In sintered and related phenomena, Ed. G.C. Kuczynski, Plenum Press, New York, 1973.

[67] S. Tsyganov, J. Kästner, B. Rellinghaus, T. Kauffeldt, F. Westerhoff, D. Wolf, "Analysis of Ni nanoparticle gas phase sintering", Physical Review B 75 (4) (2007) 045421.

[68] Y. Adda, J.M. Dupouy, J. Philibert, Y. Quere, Elements de métallurgie physique, Volume 4 : Diffusion Transformation, CEA Editor, p. 991 (1978). 
[69] W. Zhu, D. Ding, C. Xia, "Enhancement in three-phase boundary of SOFC electrodes by an ion impregnation method: a modeling comparison", Electrochemical and solid-state letters 11 (6) (2008) B83-B86.

[70] V.J. Janardhanan, V. Heuveline, O. Deutschmann, Three-phase boundary length in solidoxide fuel cells : a mathematical model, J. Power Sources, 178 (2008) 368-372.

[71] A.M. Gokhale, S. Zhang, M. Liu, A stochastic geometry based model for total triple phase boundary length in composite cathodes for solid oxide fuel cells, J. Power Sources, 194 (2009) 303-312.

[72] A. Ali, X.Wen, K. Nandakumar, J. Luo, K.T. Chuang, Geometrical modeling of microstructure of solid oxide fuel cell composite electrodes, J. Power Sources 185 (2008) 961 966.

[73] D. Chen, H. He, D. Zhang, H. Wang, M. Ni, Percolation theory in solid oxide fuel cells composite electrodes with a mixed electronic and ionic conductor, Energies, 6 (2013) 1632-1656. [74] R.K. Sharma, H. Moussaoui, J. Debayle, Y. Gavet, G. Delette, P. Cloetens, J. Laurencin, "Microstructural correlations for specific surface area and triple phase boundary lengths for typical electrodes of solid oxide cells", to be submitted in Journal of Power Sources (2018).

[75] E. Lay-Grindler, J. Laurencin, G. Delette, J. Aicart, M. Petitjean, L. Dessemond, "Micro modelling of solid oxide electrolysis cell: From performance to durability", International journal of hydrogen energy 38 (17) (2013) 6917-6929.

[76] J. Laurencin, M. Hubert, K. Couturier, T. Le Bihan, P. Cloetens, F. Lefebvre-Joud, E. Siebert, "Reactive mechanisms of LSCF single-phase and LSCF-CGO composite electrodes operated in anodic and cathodic polarisations", Electrochimica Acta 174 (2015) 1299-1316.

[77] J. Laurencin, F. Lefebvre-Joud, G. Delette, "Impact of cell design and operating conditions on the performances of SOFC fuelled with methane", Journal of Power Sources 177 (2) (2008) 355-368.

[78] J. Laurencin, D. Kane, G. Delette, J. Deseure, F. Lefebvre-Joud, "Modelling of solid oxide steam electrolyser: impact of the operating conditions on hydrogen production", Journal of Power Sources 196 (4) (2011) 2080-2093.

[79] J. C. Njodzefon, D. Klotz, A. Kromp, A. Weber, E. Ivers-Tiffée, "Electrochemical modeling of the current-voltage characteristics of an sofc in fuel cell and electrolyzer operation modes", Journal of The Electrochemical Society 160 (4) (2013) F313-F323 


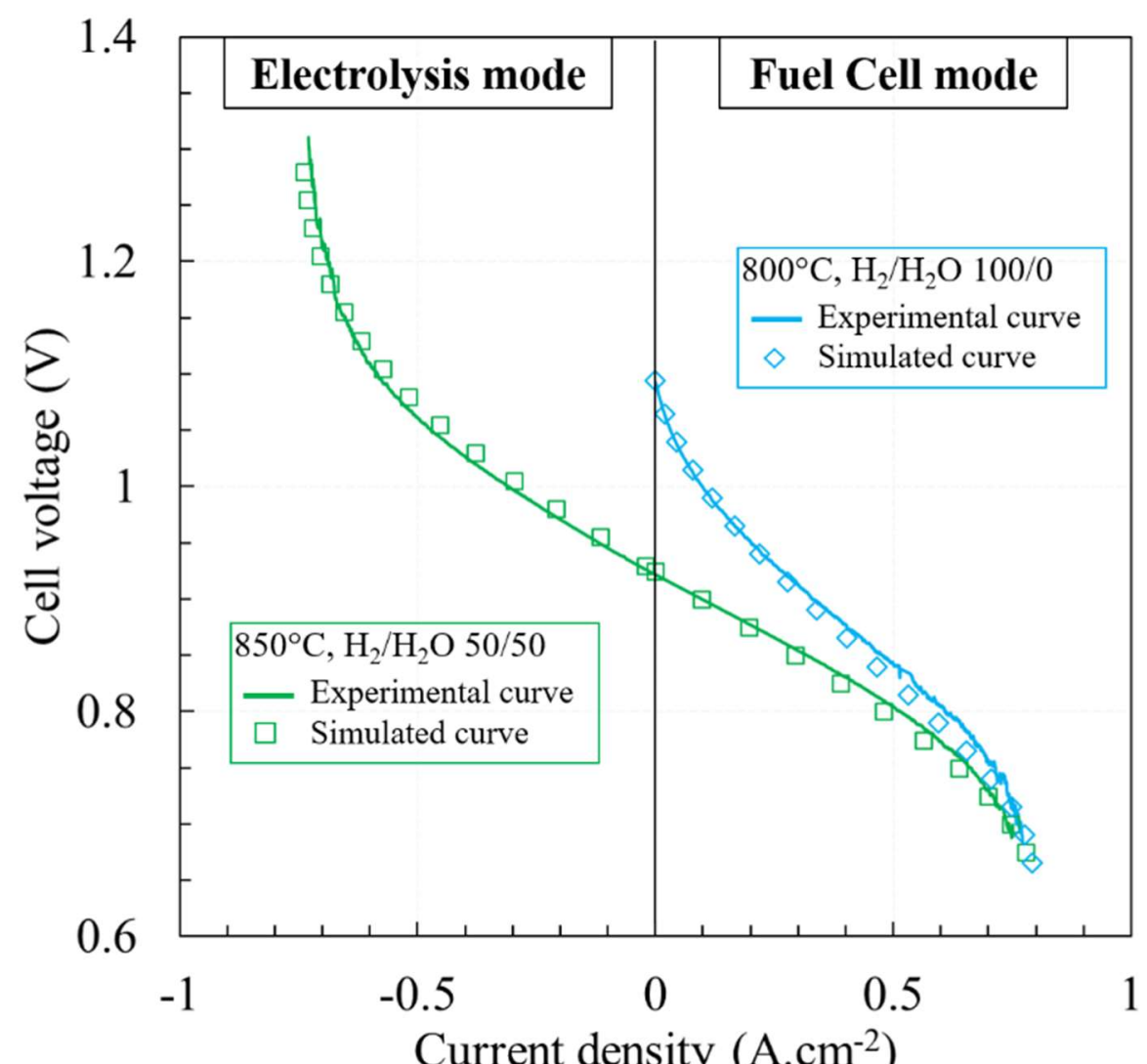

Fig. 1. Comparison between experimental and simulated polarization curves for a fresh cell in different conditions. 

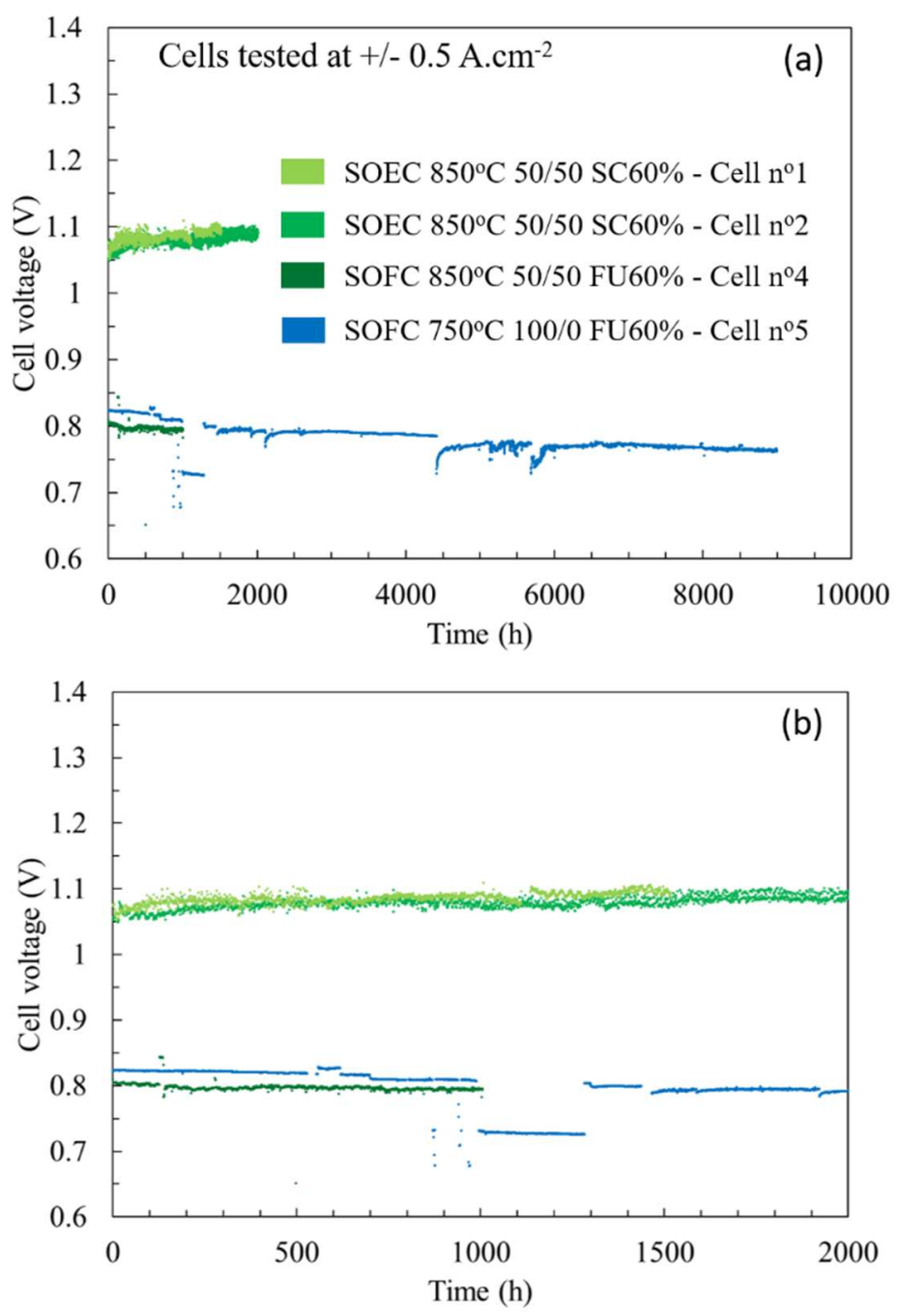

Fig. 2. (a) Durability curves in fuel cell and electrolysis mode for cells tested at $+/-0.5 \mathrm{~A} . \mathrm{cm}^{-2}$ and (b) a zoom-in of the first 2000 hours for the same cells. A short period of $300 \mathrm{~h}$ at FU $80 \%$ and $i=0.66 \mathrm{~A} . \mathrm{cm}^{-2}$ can be seen for cell $\mathrm{n}^{0} 5$. 

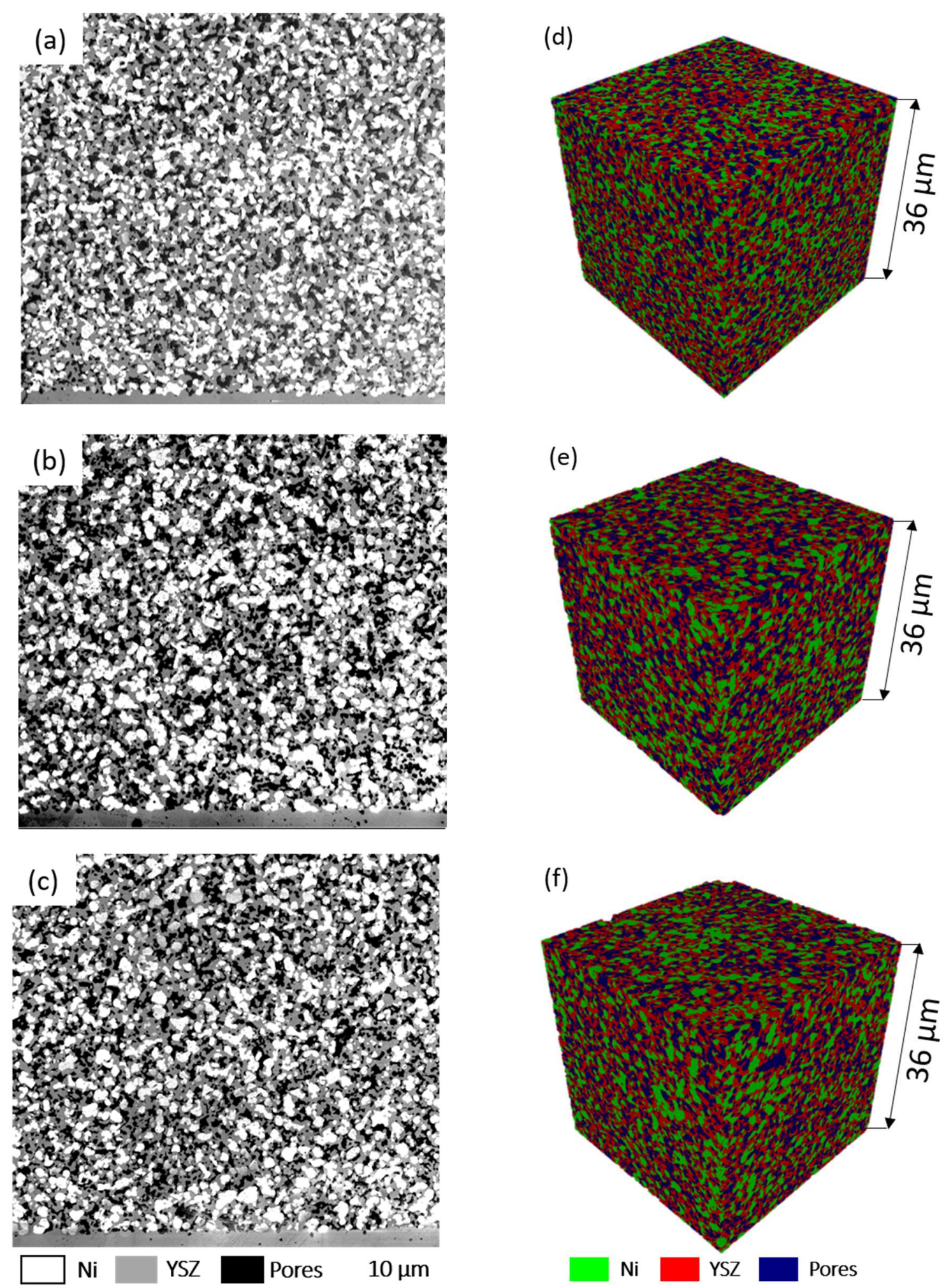

Fig. 3. Post-mortem characterization of the $\mathrm{H}_{2}$ electrode. SEM images of the electrode/electrolyte interface for: (a) the pristine cell, (b) Cell $\mathrm{n}^{\circ} 4$ and (c) Cell $\mathrm{n}^{\circ} 5$. The corresponding volume renderings obtained by X-ray nanotomography are presented for (d) the pristine cell, (e) Cell $n^{\circ} 4$ and (f) Cell $n^{\circ} 5$. 

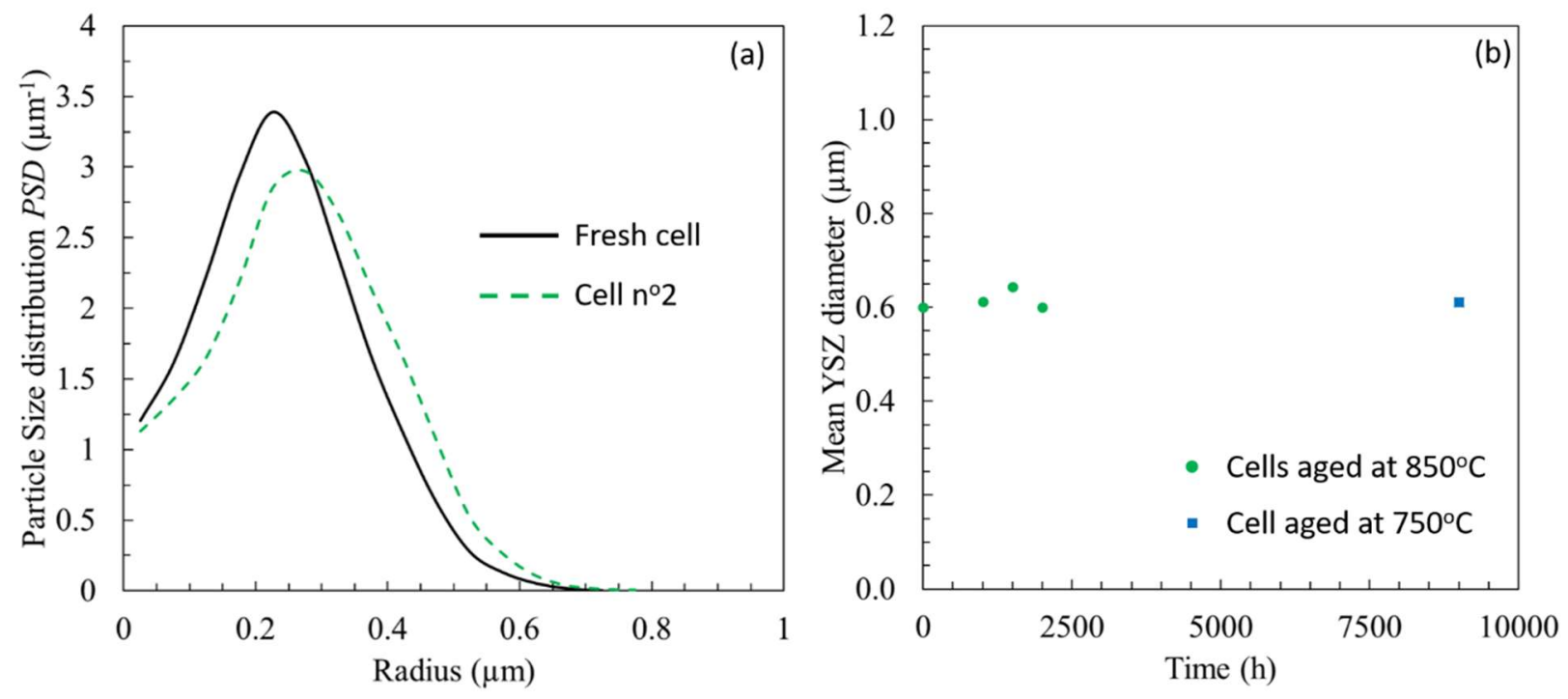

Fig. 4. (a) Particle Size Distribution of the Ni phase for the pristine cell and Cell $n^{\circ} 2$. (b) Mean diameter for the YSZ phase measured on the 3D reconstructed volume for the tested cells. 


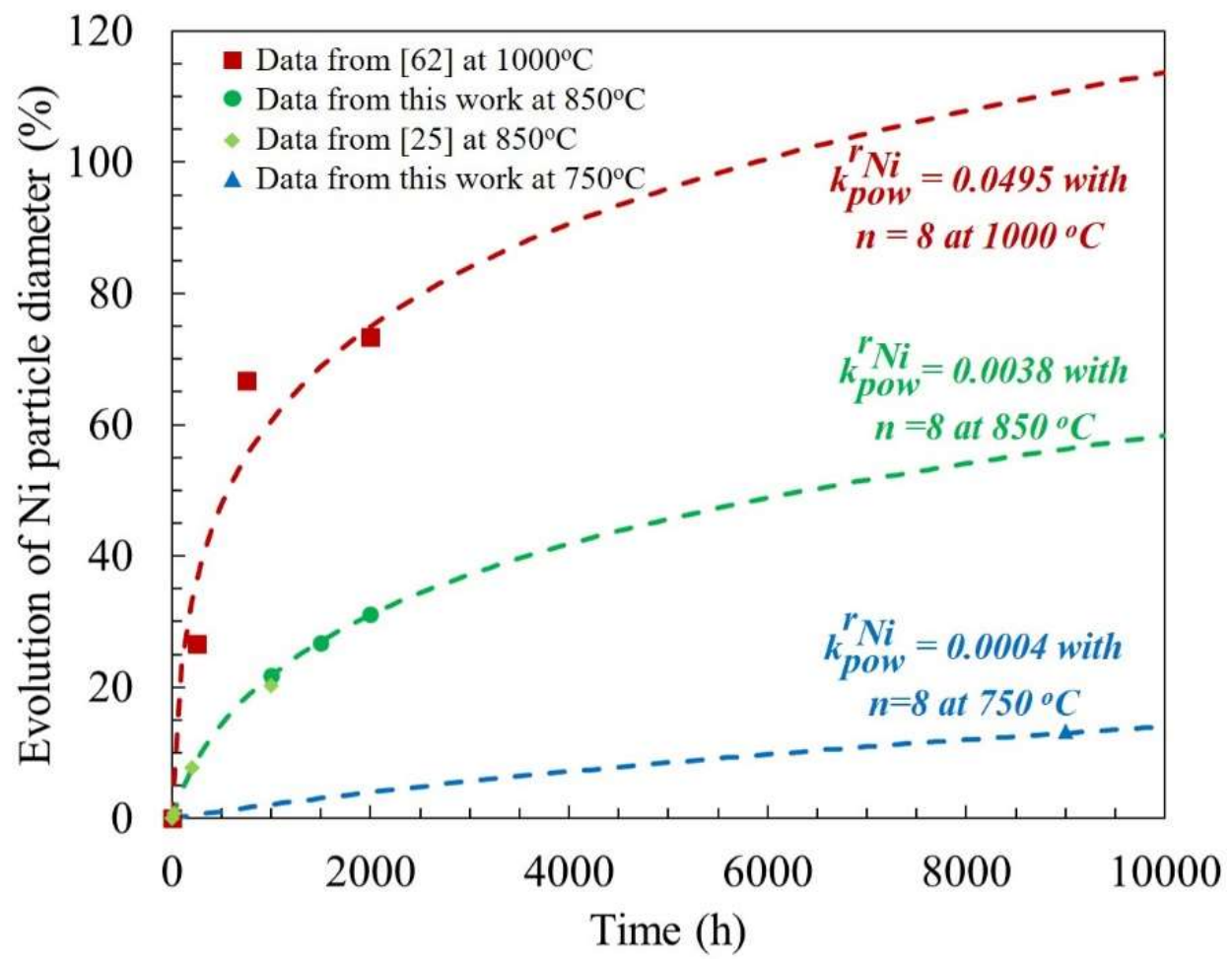

Fig. 5. Evolution over time of the Ni mean particle diameter measured on the reconstructed volume fitted by a power law model at different temperatures using an exponent equal to 8 . 


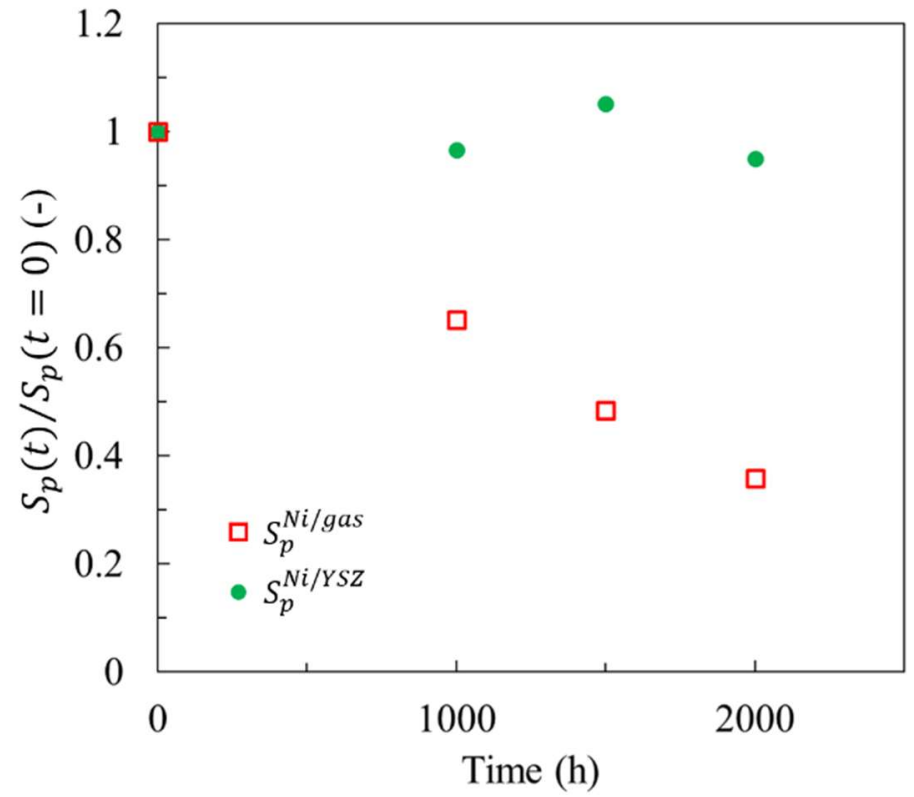

Fig. 6. Evolution over time of the specific surface area measured on the reconstructed volume between $\mathrm{Ni} / \mathrm{YSZ}$ and $\mathrm{Ni} / \mathrm{gas}$ for the cells tested at $850{ }^{\circ} \mathrm{C}$. The data are normalized by the initial specific surface area. 

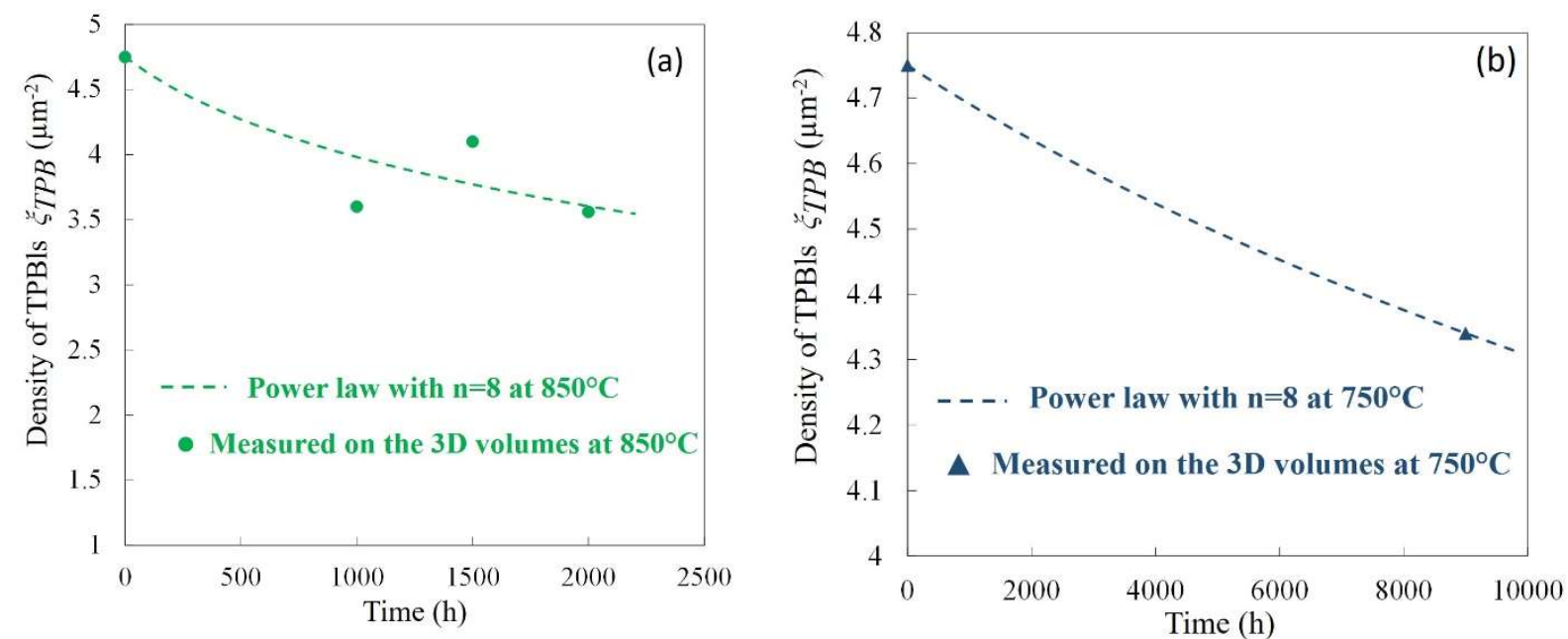

Fig. 7. Evolution over time of the density of TPBls measured on the reconstructed volumes and fitted by a power law model (with $n=8$ ) (a) at $850^{\circ} \mathrm{C}$ and (b) $750{ }^{\circ} \mathrm{C}$. 

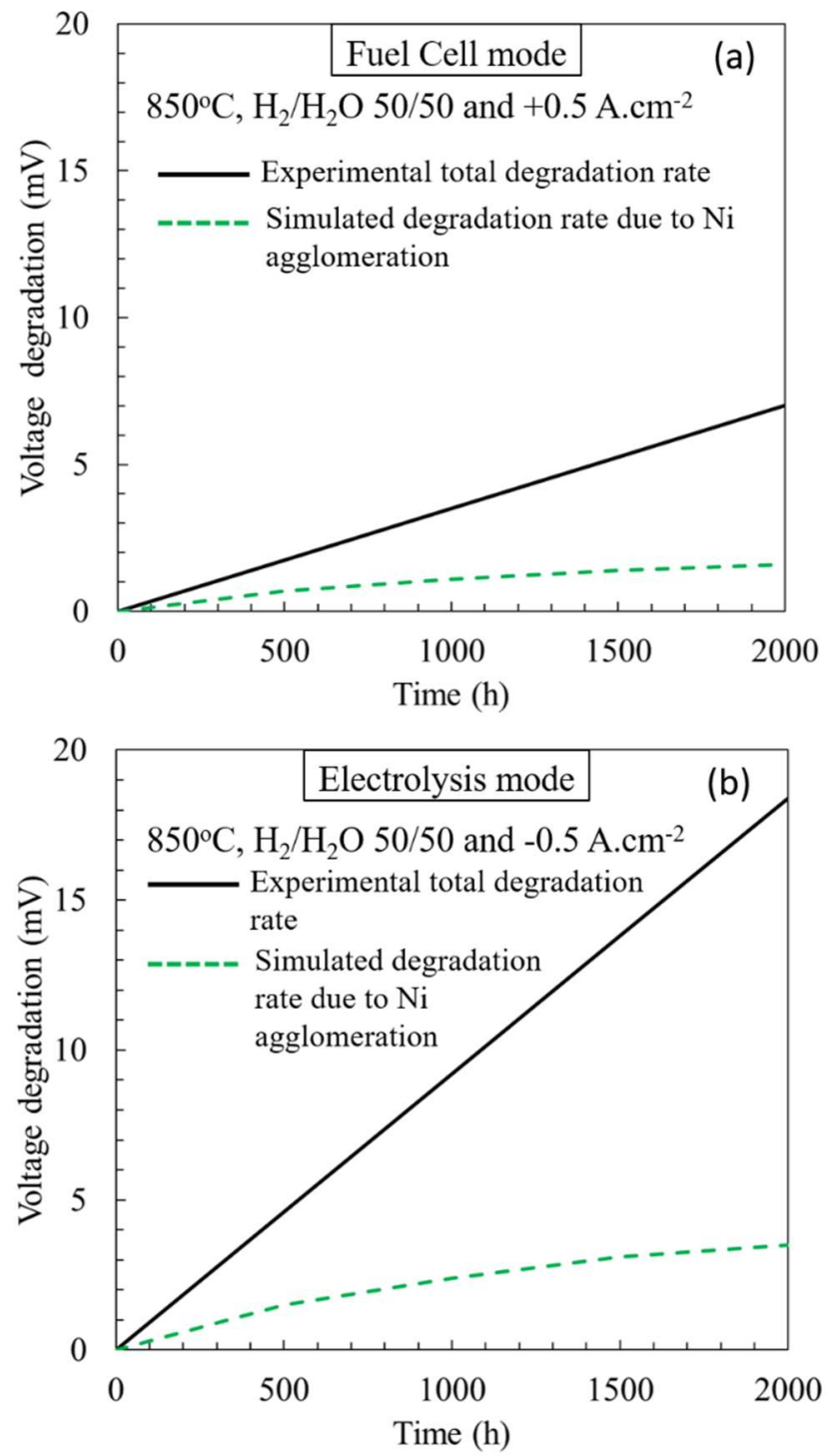

Fig. 8. Experimental degradation rate compared to the simulated contribution from the $\mathrm{Ni}$ agglomeration in (a) fuel cell mode and (b) electrolysis mode. 